NBER WORKING PAPER SERIES

\title{
BRANCH BANKING, BANK COMPETITION, AND FINANCIAL STABILITY
}

\author{
Mark Carlson \\ Kris James Mitchener \\ Working Paper 11291 \\ http://www.nber.org/papers/w11291
}

\author{
NATIONAL BUREAU OF ECONOMIC RESEARCH \\ 1050 Massachusetts Avenue \\ Cambridge, MA 02138 \\ April 2005
}

This paper is forthcoming in the Journal of Money, Credit and Banking. We thank Waiyi Poon for valuable research assistance and Joe Mason, Bill Sundstrom, David Wheelock, Eugene White and conference and seminar participants at the Cliometric Society Sessions of the ASSA Meetings, the Economic History Society Annual Meetings, NBER-DAE, and Yale University for comments and suggestions. The views presented in this paper are solely those of the authors and do not necessarily represent those of the Federal Reserve System or its staff. The views expressed herein are those of the author(s) and do not necessarily reflect the views of the National Bureau of Economic Research.

(C2005 by Mark Carlson and Kris James Mitchener. All rights reserved. Short sections of text, not to exceed two paragraphs, may be quoted without explicit permission provided that full credit, including $\odot$ notice, is given to the source. 
Branch Banking, Bank Competition, and Financial Stability

Mark Carlson and Kris James Mitchener

NBER Working Paper No. 11291

April 2005

JEL No. G21, N22, E44

\begin{abstract}
$\underline{\text { ABSTRACT }}$
It is often argued that branching stabilizes banking systems by facilitating diversification of bank portfolios; however, previous empirical research on the Great Depression offers mixed support for this view. Analyses using state-level data find that states allowing branch banking had lower failure rates, while those examining individual banks find that branch banks were more likely to fail. We argue that an alternative hypothesis can reconcile these seemingly disparate findings. Using data on national banks from the 1920s and 1930s, we show that branch banking increases competition and forces weak banks to exit the banking system. This consolidation strengthens the system as a whole without necessarily strengthening the branch banks themselves. Our empirical results suggest that the effects that branching had on competition were quantitatively more important than geographical diversification for bank stability in the 1920s and 1930s.

Mark Carlson

Federal Reserve Board

$20^{\text {th }}$ and Constitution Ave, NW

Washington DC 20551

mark.a.carlson@frb.gov

Kris James Mitchener

Department of Economics

Leavey School of Business

Santa Clara University

Santa Clara, CA 95053

and NBER

kmitchener@scu.edu
\end{abstract}




\section{Branch Banking, Bank Competition, and Financial Stability}

One of the foundations of the theoretical literature on banking regulation is that branch banking leads to more stable banking systems by enabling banks to better diversify their assets and widen their depositor base (Gart 1994, Hubbard 1994). This conventional wisdom has been used to argue that historical banking crises in the United States, especially those of the 1930s, would have been less severe had the U.S. permitted widespread branch banking (Friedman and Schwartz 1963, Calomiris 2000). The empirical literature examining U.S. banking instability during the Great Depression, however, has not universally confirmed this prediction. In fact, this research presents a paradox. Studies using aggregate bank failure data from the Depression find that states that allowed branch banking had lower failure rates than those that only allowed unit (or single-office) banking (Wheelock 1995, Mitchener 2000a, 2004); although the result is consistent with the diversification hypothesis, these studies do not test the precise channel through which branching reduced failures. In contrast, studies using individual bank data from the same period cast doubt on the common view that the stabilizing benefits of branching operated via increased diversification opportunities. Calomiris and Mason (2000) and Carlson (2004) find that banks with branches were more likely to fail than unit banks, in part because they pursued strategies to reduce reserves rather than to diversify their portfolios.

In this paper, we resolve this empirical puzzle by focusing on an additional channel through which branch banking could affect financial stability: increased competition. Our hypothesis is that, faced with heightened competition, banks that are only marginally profitable are forced out of the banking system either through merger or voluntary liquidation. As these weaker banks close, the overall stability of a state's banking system improves through consolidation. Thus, in the 1920s and 1930s, states 
allowing branch banking experienced lower failure rates without the branch banks themselves necessarily being the strongest banks.

Our hypothesis draws on the theoretical and empirical literature that examines the removal of legal restrictions on competition, and then links it to the literature on bank failures. Although policymakers often debate whether there are tradeoffs between competition and stability, surprisingly little theoretical or empirical research has analyzed these linkages in depth (Allen and Gale 2000). ${ }^{1}$ Consistent with the hypothesis posited here, Berger and Hannan (1998) find that banks not exposed to competition are able to exercise monopoly power and tend to be less efficient than banks subject to more competition. When laws restricting competition are relaxed, bank profits generally decline. This has been found both within the United States (Amel and Liang 1997) and internationally (Claessens, Demirguc-Kunt, and Huizinga 1998, Levine 1996). Moreover, the increase in competition resulting from the removal of branching restrictions has been linked to the weeding out of weak banks (Jayaratne and Strahan 1998, Stiroh and Strahan 2003). We similarly argue that the expansion of branching in the 1920 s facilitated an increase in competition. To help clarify the theoretical debate over the effects of competition on financial stability, we directly test how the growth of branching influenced bank competition and how this in turn affected bank failures.

Since our hypothesis emphasizes changes in the competitive environment induced by the onset of branch banking, it is necessary to test our model using data from a period when branch banking was expanding in scope. Moreover, because we want to test how branching influences the stability of banking systems, we also need to examine a period when there were numerous failures. In this respect, the experience of the U.S. banking system from 1920-30 is ideal since branching was expanding rapidly (Figure 1), and

\footnotetext{
1 "On the one hand, there are many models of competition in the literature including models of bank regulation in a competitive environment. On the other hand, there is a well-developed literature on bank crises...But there is little on the impact of competition on stability." (Allen and Gale, 2000, p.268). Important exceptions are Koskela and Stenbacka (2000) and Matutes and Vives (1998); however, this newer theoretical literature presents conflicting views on how competition affects financial stability.
} 
because the 1920s were characterized by a large number of bank failures (Figure 2). ${ }^{2}$ Finally, examining this period allows us to compare our results to existing research on the Great Depression and resolve the paradox that currently exists in the literature.

Our hypothesis has several testable propositions. First, the expansion of branching should change the competitive environment. If branch banking removes weaker banks from a banking system, then states permitting branch banking should experience higher merger and voluntary liquidation rates and lower entry rates (by new banks) than states prohibiting it. Second, over time more competition in states permitting branch banking should result in lower profit levels. Finally, if the competitive shakeout induced by branching stabilizes banking systems by removing weak banks from the system, then in the long run failure rates should be lower in states where branch banking was expanding. The link between branching, competition, and stability ought to be present even after controlling for any benefits to stability coming from improved geographical diversification of bank portfolios. We draw on the bifurcated nature of the dual banking system that existed in the 1920 s to design a statistical test to discriminate between the effects of geographical diversification and competition due to branching.

Our empirical results support the predictions of the competition hypothesis. States in which branching was more prevalent experienced more mergers and voluntary liquidations during the 1920s. We also find that, although there was significant consolidation in the banking sector in states allowing widespread branch banking, profits were lower on average in these states, suggesting that branching led to increased competition rather than monopoly power. To test whether branching reduced failures, we first confirm that our data produce the usual state-level result that states allowing branching or those with more branch offices had lower failure rates. We then construct

\footnotetext{
${ }^{2}$ Chapman and Westerfield (1942) describe how the issue of branch banking gained national attention during the 1920s, in part because it was spreading rapidly in states such as California and prompting federal regulators to reconsider their longstanding prohibitions against it.
} 
proxies for the portfolio diversification and competition channels of branching and test whether their inclusion affects this result. Our econometric evidence shows that, at least for national banks, the consolidation effects were quantitatively more important than increased portfolio diversification opportunities for banking stability during this period. These results suggest that, at the onset of the Great Depression, there were still many weak banks in states prohibiting branch banking; the real shock of the 1930s caused many of these to fail. However, in states that permitted branching, weak banks had been pruned from the system, and failures were consequently lower at the systemwide level. Thus we resolve the paradox in the existing literature by showing that the expansion of branching improved stability at the statewide level through the competitive shakeout process without necessarily improving individual banks' ability to diversify away risk during a large shock such as the Great Depression.

The paper proceeds as follows. Section 2 discusses the previous literature on branching and financial stability. In section 3, we present our hypothesis for resolving the existing puzzle in the literature. The next section tests the consolidation hypothesis and some of its implications for bank competition and financial stability. Section 5 provides concluding remarks.

\section{Section 2. The Effects of Branch Banking on Financial Stability}

An argument commonly articulated in the literature is that branch banking stabilizes banking systems by reducing their vulnerability to local economic shocks: branching enables banks to diversify their loans and deposits over a wider geographical area or customer base. ${ }^{3}$ Restrictions on branching have been linked to the instability of banking systems. Calomiris (2000) argues that bank failures were more prevalent in

\footnotetext{
${ }^{3}$ Studies by Wacht (1968) and Lauch and Murphy (1970) find reduced variance in deposit flows for branch banks. Cherin and Melcher (1988) find that branching has moderating effects on asset returns.
} 
regions of the United States without branch banking as well as in countries lacking it. Friedman and Schwartz (1963) suggest that the absence of branching in the U.S. increased the severity of the banking panics during the Great Depression. Moreover, they argue that the U.S. experience stands in contrast to Canada, which experienced banking distress during the Depression but not widespread failures and a collapse of its banking system. ${ }^{4}$ The notion that branch banking stabilizes banking systems by increasing diversification opportunities is in fact an argument with old roots (Sprague 1903). In the 1920s, proponents of branch banking used this argument to encourage state legislatures to adopt laws legalizing branch banking (Preston 1924, Southworth 1928).

Research examining the effects of branching at the aggregate level generally supports the hypothesis that allowing branch banking increases systemic stability. Wheelock (1995) studies the effects of different state banking regulations on bank failures during the Depression and finds that states that allowed branch banking tended to have lower failure rates. Mitchener (2000a, 2004) further examines state- and countylevel bank failure rates. Controlling for economic fundamentals and differences in both state supervision and regulation, he also finds that states with legalized branching had lower failure rates during the Depression. Comparing 25 different countries during the Great Depression, Grossman (1994) finds that countries with large branching networks were less likely to experience banking crises. ${ }^{5}$ Although the studies that rely on aggregate data find a positive correlation between branch banking and financial stability, they do not establish the precise channel through which branching improved stability. ${ }^{6}$ It is

\footnotetext{
${ }^{4}$ Drummond (1991) and White (1983) make a similar argument. Kryzanowski and Roberts (1993), however, find that nationwide branch banking did not prevent banks in Canada from becoming technically insolvent.

${ }^{5}$ Many of these studies also include some measure of bank concentration as an explanatory variable. Although none of them provides an interaction term for branch banking and their measure of concentration, it is possible that these two effects worked together to influence failure rates. In section 4, we relate our consolidation hypothesis to the issue of banking concentration. Our emphasis, however, differs in that we are testing whether changes in bank concentration are an outcome of branching laws and whether this in turn affected bank profitability.

${ }^{6}$ Wheelock (1995) attributes the positive correlation between restrictions on branch banking and failure rates to limited diversification. Similarly Alston, Grove, and Wheelock (1994) also consider the impact of
} 
therefore possible that the stability effects of branching are related to something besides or in addition to diversification.

Studies using data on individual banks operating in the 1920s and 1930s paint a different picture of the effects that branching has on the survivorship of individual banks, and they cast doubt on the common view that the stabilizing benefits of branching operated via increased diversification opportunities. Calomiris and Mason (2000) find that, during the Depression, Federal Reserve members that were branch banks tended to fail sooner than unit banks. Also, using data on individual state banks from this period, Carlson (2004) examines three states where branch banking was relatively widespread and finds that branched banks were more likely to fail than unit banks. Furthermore, he rejects some potential reasons for this phenomenon, including insufficient diversification and over-expansion on the part of banks. Instead, he finds that branch banks used diversification to reduce their reserves rather than to lower the risk of their portfolios - a strategy that worked poorly during the global shock of the Great Depression.

Because it is difficult to reconcile the findings based on aggregate data (which report a negative relationship between bank failures and statewide branch banking) with the empirical results from studies using individual bank data (which are inconsistent with the view that the source of stability was improved opportunities for diversification), this article proposes an additional channel through which branching could have affected stability: competition. Although they do not construct a formal model, Berger, Demsetz, and Strahan (1998) argue that increased competition results in the purging of inefficient banks from the banking system. Consistent with these ideas, Jayaratne and Strahan (1998) and Stiroh and Strahan (2003) find that the branch-banking reform that began in the United States in the 1980s resulted in the removal of weaker banks from the system.

branching legislation on bank failures, and emphasize that branching may reduce a bank's susceptibility to distress in a particular area; however, they do not find that the ratio of (non-home-office) branches to total banks helps to explain the cross-state variation in failure rates during the $1920 \mathrm{~s}$. 
Additionally, Koskela and Stenbacka (2000) suggest that greater competition decreases interest rates and increases the likelihood that borrowers are able to remain solvent and repay their loans. These studies suggest that the introduction of competition (in our case, driven by the growth of branch banking) may improve the stability of banking systems. On the other hand, Matutes and Vives (1998) argue that raising the level of competition causes an increase in failures as lower profits resulting from competition encourage banks to take on more risk. ${ }^{7}$ We are not aware of any previous studies that systematically test the effects of competition on the stability of banking systems in particular. ${ }^{8}$

\section{Section 3. Branch Banking and Competition in the 1920s}

As figure 1 shows, the total number of branches operated in the United States nearly tripled between 1920 and 1930, rising from 1,281 to 3,518. Many of these branches were located in home-office cities and the number of these branches more than doubled, increasing from 508 in 1920 to 1,131 in 1930 (Federal Reserve 1931, vol. 2). We hypothesize that this expansion of branching networks increased the level of competition in states that allowed branching to occur. As a result of this dynamic process, banks that were only marginally profitable prior to the increase in competition would become unprofitable due to the increase in competition. In turn, these banks would likely merge with existing banks or voluntarily liquidate. ${ }^{9}$ Also, because it is less costly to open a branch than a new bank, it is likely that fewer new banks would be able to find an unexploited profitable niche and enter the market despite the fact that regulatory barriers

\footnotetext{
${ }^{7}$ Demsetz and Strahan (1997) find that consolidation for bank holding companies (BHCs) enhanced diversification following regulatory reform in 1994, but that larger BHCs then operated with lower capital ratios and increased their risky lending.

${ }^{8}$ Kaminsky and Schmukler (2002), however, compare broad financial systems of different countries between the early 1970s and the late 1990s and find that, although reducing barriers to external competition initially results in some turmoil, the long run effect of deregulation is increased stability.

${ }^{9}$ Wheelock and Wilson (2000) find that, during the 1980s and 1990s, inefficiency reduced the likelihood that a bank would be acquired. Carlson (2001), however, finds that during the early 1930s, acquired banks were generally weaker than other banks.
} 
to entry have been removed. With the exit of the weakest banks, the economic viability of the average bank would increase and the rate of failure for banks within that state would decline. ${ }^{10}$ The idea that the removal of barriers to competition would lead to a reduction in the number of banks in the banking system is consistent with the model by Economides, Hubbard, and Palia (1996).

Why should these competitive forces apply to the introduction of new branches (as a result of legal changes) and not simply to the emergence of new unit banks in the 1920s? First, banks with branches were more cost-effective, since some jobs at different branches could be consolidated and performed at the head office, thus reducing employment costs (Federal Reserve 1931, vol. 2, p. 224.) Also, start-up costs were lower, and in some states, regulators required less capital for new branches than for new unit banks (Southworth 1928). Second, new branches that were set up in previously restricted markets may have been more adept at realizing higher rates of return than comparable new unit banks since branches could transfer deposits out of the local market to regions where capital was in higher demand. ${ }^{11}$ The ability to obtain a cost advantage through branching and realize higher rates of return made entry into existing local markets easier for branch banks than new unit banks. Indeed, branch banking may have been instrumental in bringing banking and banking competition to small towns. Calomiris (2000, Chapter 1) makes a similar argument. In 1931 (the only year for which we have so far been able to locate the distribution of branches by town size), nearly half of all branches outside the home-office city were located in towns of less than 2,500 people (Table 1). Figure 3 shows the locations of branches outside the home-office city.

\footnotetext{
${ }^{10}$ By limiting the development of secondary markets, entry barriers such as restrictions on branching could also prevent productive assets of weak banks from being digested or taken over by more efficient banks. Without the existence of local competition to absorb bank assets, weak banks may have been forced to sell productive assets in thin markets at fire sale prices or not at all, in turn increasing the likelihood of bank failures within the system.

${ }^{11}$ Morgan, Rime, and Strahan (2003) provide another channel through which diversified banks improve stability - shifting capital between regions to dampen economic shocks.
} 
Laws that permitted statewide branching applied only to state-chartered banks (which were regulated by state banking departments) while the data used below to test this hypothesis are for national banks (which were regulated by the Office of the Comptroller of the Currency). The logic of our hypothesis, however, still applies to national banks since they would be subject to increased competition from the state banks that were allowed to establish branches. ${ }^{12}$ Indeed, it may actually be better for testing the competition hypothesis since the vast majority of national banks had no branches outside the home-office city over our period and therefore enjoyed no effective geographical diversification benefits. Excluding California, the country's nearly 8,000 nationally chartered banks operated 18 branches outside the home-office city in 1925. In 1930 this number was 27 (Federal Reserve Board of Governors 1943). Since our sample consists of national banks, and only a few of them branch outside the headquarter city, any observed or unobserved channels through which branching might affect both competition and diversification are likely to be less of a problem. Finally, using a sample consisting of national banks has the additional advantage that the regulatory environment and the attitudes of regulators regarding bank mergers were more uniform than those concerning state banks.

It has been shown by Calomiris and Mason (2000), among others, that less profitable banks were more likely to fail during the Great Depression. A key component of our hypothesis is that in the long run fewer of these banks would exist in states that allowed branch banking, because the competitive pressures associated with the rise of branch banking networks prior to the Depression would have forced weak banks to exit from the banking system earlier in the decade. In states without the competitive pressures of branch banking, more weak banks would still exist at the start of the Depression and

\footnotetext{
${ }^{12}$ Additionally, state banks that converted into national banks were permitted to keep branches they had established while they were state banks, enabling branch banks to become national banks through a legal technicality.
} 
these states would therefore have more banks that would be likely to fail during the subsequent downturn. This interpretation is consistent with the findings in Mitchener (2000a, 2004) and Wheelock (1995): states allowing branch banking had lower failure rates than those prohibiting it. And it would also be true even though it was not necessarily the case that branch banks were the survivors.

The alternative hypothesis, that a banking system with branching is more diversified and therefore more stable than a banking system with only unit banks, presupposes that the two systems are in equilibrium. The banking system of the United States during the 1920s and 1930s, however, was in the process of transition. As noted above, branching was expanding rapidly in some states and the total number of banks was declining steadily from 29,715 in June 1920 to 23,855 by June 1930 (Federal Reserve 1943). The growth in branch banking during the 1920s was facilitated by a variety of legal and technological changes. In 1922, the Comptroller ruled that national banks could, "under the law, establish agencies, teller windows, or additional offices within the city of the parent bank provided state banks were permitted to operate branches in that state (Chapman and Westerfield, 1942, p.97)," although these offices could not issue loans and were not full-fledged branches. Possibly seeing these offices as one step away from approval by the Comptroller of full-fledged branch banking for national banks, state banks may have responded by increasing their branching networks in order to compete with national banks. Relationships with correspondents were weakened due to amendments of the Federal Reserve Act in 1917 (which put check clearing in the hands of the Federal Reserve and required national banks to hold their entire reserve requirement at the Federal Reserve), possibly inducing banks to pursue the loss of deposits by buying banks and converting them to branches. Dramatic improvements in road networks and improvements in telephone networks likely improved the ability of managers to oversee branch networks. And rising urbanized populations in the newer cities of Los Angeles and Detroit (both augmented by the rise of 
the automobile, the former via the conversion of rails to roads and the latter which served as the industry's manufacturing hub) also led to an increase in demand for banking services. Both cities realized dramatic increases in the number of branch banking offices in the 1920s. It is also likely that more banks were willing to develop branch networks during the 1920s as they observed the success of branch banks in places such as California. ${ }^{13}$ It is this structural change in the banking system wrought by these factors that motivates our hypothesis. The key role played by this change in the banking system suggests that our explanation is specific to the United States and may not apply to other economies during the 1920s, such as Canada and the United Kingdom, which had removed barriers to branching earlier and likely had completed the transition to a branch banking system. That is, as branching expanded rapidly in some U.S. states in the 1920s shakeout took place, initially causing exit and later reducing bank failures.

Because the growth in branching is attributable largely to shifts in the relationships of banks with each other, technological progress, and population/economic growth rather than changes in regulation specifically concerning branching, we use changes in actual branching activity over time, and across states, rather than changes in branching laws, to examine the effect of branching on a state's banking system. We argue that using actual branches provides a more complete picture of the effect that branching might have on the competitive environment because the laws regulating the establishment of branches varied substantially so that variables categorizing regulations capture quite different situations. ${ }^{14}$

\footnotetext{
${ }^{13}$ California's branching network developed more quickly and extensively than any other state in the decade, in part due the financial entrepreneur, A.P. Giannini, who created an extensive branching network for the Bank of America. This spurred competing large banks in California to develop branching networks, especially in Los Angeles, to fight Bank of America's geographical expansion. Given the size of Bank of America's branching network in California, a change in its charter in 1927 (from state to national) could have a large impact on the results in our paper, so later we test whether our results on stability are sensitive to its inclusion.

${ }^{14}$ For example: Massachusetts allowed trust companies to have one branch in the same city as the home office; New York allowed unlimited branching in the city of the bank's home office if the population of the city exceeded 50,000; Louisiana allowed banks to have up to two branches, which could be located in the parish of the home office; and California allowed statewide branching.
} 
One notable change in the legal environment in the 1920s was the McFadden Act of 1927, which allowed national banks to establish local branches in the city of their home office if state law allowed branching. However, the Act imposed several restrictions: national banks could open no new branches in cities with fewer than 25,000 people, only two branches in cities with populations between 50,000 and 100,000, and at the discretion of the Office of the Comptroller of the Currency for cities of over 100,000 (Tippetts, 1929).

It should be noted that the expansion of branching (and consequently the consolidation of the banking system) in the 1920s, which was driven by the establishment of the Federal Reserve, technological changes, population growth, and economic growth, is quite different from expansion of branching in the 1980s and 1990s, which appears to have been more strongly influenced by changes in regulation (Stiroh and Strahan 2003, Kroszner and Strahan 1998). Thus, focusing on a measure of branching activity is likely to better capture the effect of branching on the banking system during the 1920s than the shifts in regulation that have played a prominent role in dealing with the expansion of branching in recent periods.

Our hypothesis, which emphasizes how the expansion of branch banking within a state increases the competitive pressures on inefficient banks and can induce them to merge or voluntarily liquidate, is consistent with recent research examining the effects of bank deregulation (DeYoung, Hasan, and Kirchoff 1998, Berger, Demsetz, and Strahan 1999, Jayaratne and Strahan 1998, Stiroh and Strahan 2003). However, it stands in contrast to one of the longstanding populist arguments lodged against branch banking. Opponents of branch banking have often complained that it was a form of cartelization that would result in consolidation of the industry and reduced competition, and that its growth would reduce the viability of businesses in small communities by siphoning funds 
to urbanized areas. Such sentiments were widely expressed in the first quarter of the $20^{\text {th }}$ century when branching was spreading rapidly. ${ }^{15}$

While the growth of branch banking may lead to consolidation, the effects on competition are not as clear as opponents of branching suggest. In fact, the economic theory or private-interest view of regulation argues that branching restrictions are used to protect inefficient, local monopolies and restrict competition. ${ }^{16}$ The result of these intrastate regulations was less than full-scale competition in local deposit and loan markets. Chapman and Westerfield (1942, p.233) described the situation in the 1920s and 1930s:

\begin{abstract}
"Country bankers foresee danger to themselves in the possibility of inroads into their areas of operation, should the larger institutions of the cities be permitted to establish branches and compete with them in their area on equal terms. They know that such a policy would result in a reduction of interest rates in their towns and that their chances for the profitable use of their funds might be somewhat diminished unless they were prepared to go as far as their new rivals in serving customers cheaply. The alleged apprehension of unit bankers as to the monopolistic character of branch banking is, to say the least, selfish. What really motivates them is their desire to preserve their local monopolies and escape the competition of the more effective branch banks."
\end{abstract}

Our hypothesis is sympathetic to this view of regulatory impediments. It is also analogous to one that has been made in the context of the global financial services industry: just as foreign banks have brought necessary competition to inefficient domestic markets (Levine 1996, Claessens, Demirguc-Kunt, and Huizinga 1998, Folkerts-Landau and Lindgren 1998), branch banking can introduce greater competition to local markets, improving the cost and delivery of services to customers and the safety of the banking system by forcing inefficient banks to merge or go out of business.

\footnotetext{
${ }^{15}$ See, for example, the discussion in Chapman and Westerfield (1942, p.10) for examples of this view.

${ }^{16}$ See Kroszner and Strahan (1998, 2000), Mitchener (2000c), and Chapman and Westerfield (1942).
} 


\section{Section 4. Testing the Competition/Consolidation Hypothesis}

This section tests several predictions of our hypothesis, using data on national banks from the 1920s and the first two years of the Depression. First, we test whether the number of mergers and voluntary liquidations was higher (and the number of entries by new banks was lower) in states where there was more branch-banking activity. We then test whether other factors related to competition and consolidation, including the number of banks per capita and the profitability of different banks, are related to the extent of branch banking in a state. Finally, we test whether competition, induced by branching, is better at accounting for the variation in failure rates across states than the diversification argument.

\section{A. Mergers, Voluntary Liquidations, and Entry in Branch Banking States}

Our first test examines industry consolidation - whether there were more mergers and voluntary liquidations for national banks in states that allowed branch banking - and whether there were also fewer new banks established in these states. ${ }^{17}$ Table 2 summarizes the rate of entry of new national banks and rates of exits of national banks over the sample period of 1922-30 and groups by whether states permitted branch banking. (Appendix Table 1 describes the sources for our data. Detailed information on state branching laws is shown in Appendix Table 2.) As the last column of the table shows, during the 1920s, states permitting some form of branching averaged somewhat more mergers and voluntary liquidations than states that prohibited branching.

\footnotetext{
${ }^{17}$ Wheelock (1993, p.815) suggests that these changes may have occurred in the 1920s, but does not formally test this notion: "Like most Midwestern states, Kansas was a unit banking state during the 1920s, with over 1,000 small banks in operation... Had branching restrictions been removed those counties might have experienced greater consolidation, through either mergers or failures."
} 
The tabular results for the effects of branching on consolidation are tested more formally by regressing the number of exits and entries of national banks on a measure for branching activity in the state. Using observations on each state $i$, we estimate the following function:

(1) COMPETITION $_{i}=\boldsymbol{f}\left\{\beta_{1} B_{R A N C H}+\beta_{2} B A N K S / C A P_{i}+\beta_{3} A G R Y_{i}+\beta_{4} D_{E P I N S}+\right.$ $\left.\beta_{5} B A N K S_{i}\right\}$,

where COMPETITION is specified as: (1) the number of mergers, (2) voluntary liquidations, or (3) new branches for national banks. ${ }^{18} B R A N C H$ is a measure of the extent of branching in the state; BANKS/CAP is the number of state and national banks per person, $A G R Y$ is the share of a state's income from agriculture in 1920, BANKS is the $\log$ number of national banks, and DEPINS is a dummy variable that equals one for states with deposit insurance systems.

Since exits and entries take on discrete integer values and are bounded below by zero, we analyze the number of exits and entries employing count data analysis, where the data are pooled across states. Count data analysis assumes that the dependent variable was generated through a Poisson process. Determining the effect of the independent variables shown in equation (1) involves maximizing the log-likelihood function:

(2) $\ln \mathrm{L}(\beta)=\sum_{i=1}^{n}\left\{y_{i} X_{i}^{\prime} \beta-\exp \left(X_{i}^{\prime} \beta\right)-\ln y_{i} !\right\}$,

where $y$ is the dependent variable vector, $X$ is the matrix of independent variables, $\beta$ is the coefficient vector, and $\mathrm{n}$ is the number of observations. ${ }^{19}$ When analyzing counts, it is

\footnotetext{
${ }^{18}$ It should be noted that entry of national banks is an imperfect measure of total entry, as one would also expect that the entry of state banks would be affected by branching. Additionally, some banks may prefer to enter the banking system as state banks in states allowing branching in order to establish branches, which might lead to measurement error in the dependent variable.

${ }^{19}$ The likelihood function is based on a Poisson process, although this can be modified; it involves taking the factorial of the dependent variable (noting that the factorial of zero is one).
} 
important to control for the size of the population from which the counts are produced. In the Poisson or negative binomial distribution the rate of "arrival" is constant so that the number of arrivals depends on the population size. Increasing the population by a given percentage should increase the number of arrivals by the same percentage. To correct for this, we include the log of the number of banks to account for the size of the "at-risk population" of banks. ${ }^{20}$

Count data analysis has several advantages over other estimation strategies: it treats observations with the value of zero as containing important information and takes into account the granularity in the data (the fact that the number of exits and entries can only take on whole numbers). Moreover, since entries and exits are truncated at zero rather than censored at zero, using an alternative estimator such as Tobit would produce biased estimates. When there is some evidence of overdispersion (the variance significantly exceeds the mean) in our sample, we employ a negative binomial distribution rather than the Poisson distribution. The coefficients can be interpreted as the percentage change in the dependent variable (number of entries or exits) due to a one-unit change in the independent variable.

Table 3 displays the results from cross-sectional regressions of the average number of mergers, voluntary liquidations, and entries from 1923 to 1930 on the ratio of branch offices for state and national banks to total branch and bank offices for state and national banks in $1922(B R A N C H)$ and the other explanatory variables described in equation 1. This specification enables us to examine whether cross-state variation is sufficient to identify a relationship between branching and our measures of exit. By holding our measure of branching at the 1922 level, we also alleviate concerns about the endogeneity of this variable. The estimated coefficients support the hypothesis that branch banking increases mergers and involuntary liquidations, leading to consolidation

\footnotetext{
${ }^{20}$ For a detailed treatment of count data analysis see Cameron and Trivedi (1998).
} 
in a state's banking system. Testing these three coefficients jointly suggests that branching results in a net reduction of the number of banks (the Chi-squared test statistic has a p-value of 0.02). During the 1920s, states that had more extensive branch-banking networks had more voluntary liquidations than states that allowed only unit banking (Column 1). The point estimate suggests that an increase in the ratio branch offices to total offices by 0.1 (about one standard deviation) resulted in roughly a 50 percent increase in the number of voluntary liquidations. Column 2 also shows that states with more branching activity had significantly more mergers than unit banking states during the 1920s. The coefficient on the extent of branching suggests that its effect on the number of mergers is similar to its effect on voluntary liquidations. These results are consistent with White (1995), who describes the wave of bank mergers in the 1920s and suggests that the increase in mergers and the ability to branch may have been related. In contrast to the findings for voluntary liquidations and mergers, branching activity appears to have had little impact on entry by new national banks (Column 3).

We next examine whether there is a sufficient expansion of branching activity in the early 1920s to induce exit as our hypothesis suggests. As appendix table 2 indicates, some states had passed branching laws before 1920. So even though the evidence from the tables and figures suggests that branching was expanding rapidly during the decade, in Table 4 we explicitly test whether the change in this branching ratio between 1922 and 1925 is associated with a greater average number of mergers and voluntary liquidations between 1926 and 1930. The statistically significant coefficient on the change in the branching ratio shown in Columns 1 and 2 suggests that the expansion of branching in the early 1920s had a significant role in shaking out the banking system even though some branching laws had been passed earlier.

The results from Tables 3 and 4 are also consistent with Wheelock (1993), who showed that the overall percentage change in banks per capita in the 1920 s was greatest 
in states where branching expanded the most. ${ }^{21}$ However, the decomposition presented here provides the further insight that branching encouraged banks to exit in a variety of ways. That voluntary liquidations increased suggests that the decline in banks per capita was not simply due to widespread purchases of banks by a few industry leaders. Rather the trends exhibited in the regressions are consistent with an overall increase in competition where branching was permitted.

We also estimated several alternative specifications in order to examine the robustness of the results, including pooling the data and using the legal status of branching in a state rather than the extent of branching. Table 5 tests whether the annual number of mergers, voluntary liquidations, and entries from 1923-1930 are related to level of branching activity lagged one year, where the data are pooled over the entire sample period. ${ }^{22}$ The measure for the extent of branch banking in a state is lagged one year to reduce the potential for endogeneity. ${ }^{23}$ We include year dummies in Table 5 (and in other pooled specifications in the paper) to control for any time-specific effects. This allows us to account for the changes in the macroeconomic environment and any residual effects of the changes in the regulatory environment, such as the McFadden Act, not captured by our degree of branching measures. The coefficients on the extent of branching are again positive and statistically significant at conventional levels for voluntary liquidations and mergers.

As a final robustness test regarding the exogeneity of our branching variable, in place of the measure based on the extent of branching, we use dummy variables indicating whether the state permitted branch banking. In a pooled regression, we find that states permitting statewide branching had more mergers and consolidations (Table

\footnotetext{
${ }^{21}$ And they are also consistent with Berger, Kashyap, and Scalise (1995), who show that the introduction of nationwide banking beginning in the 1980s accelerated the reduction in the number and market share of small bank organizations for the period of recent regulatory liberalization.

${ }^{22}$ There is, however, substantial variation over time in our measure of the extent of branching. On average, it changes 75 percent between 1922 and 1930 and by 30 percent between 1926 and 1930 .

${ }^{23}$ As we indicated in the previous section, since technological and legal changes were driving the increase in branch banking in the 1920s, the lagged measure of the extent of branching seems plausibly exogenous.
} 
6). We note, however, that the rest of analysis in this article focuses on our preferred measure, the extent of branching activity in a particular state, because it allows us to sidestep two definitional problems which complicate and potentially muddle the interpretation of regression results based on the legal status of branching in a state: (1) some states in the 1920s permitted limited branching, but what they permitted differed markedly and (2) some states differed in terms of what was practiced by regulators (de facto) and what was on the books (de jure). (See Appendix Table 2 for more details.)

\section{B. Consolidation and Increased Competition versus Monopoly Power}

Although the results presented in the previous section support the view that branch-banking activity increases mergers and exits, it is unclear whether this consolidation led to a more competitive banking system or to a monopolistic banking system. For example, when banks are forbidden from establishing branches, it artificially segments the market and enables unit banks to develop monopolies within particular localities. The immediate impact of branching is that it introduces competition into these geographically segmented markets. If banks that were previously insulated from the cool winds of competition are acquired or forced out of the market as a result of this increased competition, it is possible that the surviving banks in turn acquire monopoly power. This was one of the concerns of those who lobbied against more permissive branching laws in the 1920s: the end result of liberalization would simply be further concentration in the banking industry. To investigate further how statewide branching affects the competitive environment of a state's banking system, we examine the relationship between branching and two additional measures: banking sector concentration and bank profits.

We first test whether states allowing branch banking had more concentrated banking sectors by regressing measures of bank concentration on the extent of branch banking. The first measure of concentration is essentially an annual Herfindahl index of 
national banks. The Federal Reserve published data on the number of banks in different size categories with different levels of profitability for each state, for each of the years 1926-1930 (Federal Reserve Board of Governors 1931). ${ }^{24}$ The index is constructed as follows: the number of banks is multiplied by the means of the size category; these groups are aggregated to get the total value of loans and investments in the state. The mean of each size category is divided by total state assets, squared, and multiplied by the number of banks in each size category. These fractions are then added together to obtain the index. ${ }^{25}$ Since the Federal Reserve data used to construct this index are only available for 1926-30, the results for the Herfindahl index are presented for this period. The second measure is a four-firm concentration ratio based on the deposits in the largest four commercial banks (state or national) in each state for each year of our sample. This measure allows us to examine a longer sample period (1923-1930) as well as a measure based on the liabilities of banks. The third measure is simply the number of banks per capita (both state and national commercial banks), also calculated for 1923-1930. The sample consists of annual observations on each state.

Analysis using the ratio of branch offices to total bank offices of state and national banks in 1922 as our measure of branching indicates that states with more extensive branching had more concentrated banking sectors - higher Herfindahl scores, more deposits in the largest four banks, and fewer banks per capita. ${ }^{26}$ We find similar

\footnotetext{
${ }^{24}$ The size categories, based on loans and investments, are: category 1 - under $\$ 150,000$; category 2 $\$ 150,000-\$ 250,000$; category 3 - $\$ 250,000-\$ 500,000$; category 4 - $\$ 500,000-\$ 750,000$; category 5 $\$ 750,000-\$ 1,000,000$; category 6 - $\$ 1,000,000-\$ 2,000,000$; category 7 - $\$ 2,000,000-\$ 5,000,000$; category 8 - $(\$ 5,000,000-\$ 10,000,000$; category 9 - $\$ 10,000,000-\$ 50,000,000$; category $10-\$ 50,000,000$ and over. We employ the profit information below.

${ }^{25}$ Mathematically, we can write this is as: $\sum_{i=\text { size group }}\left\{\frac{\text { mean value of loans }(i)}{\left.\left[\sum_{i}(\text { mean value of loans }(i)) \text { (banks in category }(i)\right)\right]}\right\}^{2}($ banks in group $(i))$

${ }^{26}$ Our Herfindahl index is admittedly imperfect since it does not include state banks (comparable data do not exist), and state banks were on average smaller. The average assets (loans and investments) for state banks in 1926 was $\$ 1,272,183$ whereas for national banks it was $\$ 2,403,295$; state banks had $57 \%$ of total assets in the commercial banking system in this year. Nevertheless, since our other two measures of
} 
results if we pool the data and regress measures of bank concentration on the ratio of branch offices to total offices lagged one year (Table 7). Thus, regardless of the measure, states with more extensive branching tended to have more concentrated banking systems.

Next, we examine how branch banking affected bank profits. Since national banks were all regulated at the national level by the Office of the Comptroller of Currency and were largely restricted in their ability to have branches, differences in the level of competition that they faced would be a significant factor in creating differences in profit levels between states. Finding lower profits in states that witnessed a growth in branch banking would indicate that the national banks faced greater competition from state banks in these locations. ${ }^{27}$

To test how branching laws affect profitability, we use profit data on national banks that are available from 1926-30 and that are decomposed by both size category (based on loans and investments) and by state. Rather than listing the actual profit rates, the Federal Reserve (1931) grouped the data into seven profit ranges, using the percentage return to capital as the measure of profitability. ${ }^{28}$ The data set thus has up to 70 observations per state, per year because there are 7 profit ranges for each of the 10 bank size categories. ${ }^{29}$ Because the ranges are ordered but the distance between them is not constant, an ordered logit is estimated using weights equal to the number of national banks in each size category $s$, state $i$, and year $t$, earning a given level of profits. We estimate the following function:

concentration also show that states with more branching activity had more concentrated banking systems, we are confident that our result is robust.

${ }^{27}$ Lower profitability may also result from higher merger costs; however, due to branching restrictions on nationally-chartered banks, this interpretation is more likely to apply to state banks than the national banks used in our sample. Alternatively, national banks may have higher profits if branching leads to so much industry consolidation that surviving banks are able to generate oligopoly profits. Higher profits may also result if competition removes a sufficient number of inefficient national banks from the banking system.

${ }^{28}$ These ranges are: deficit of $6 \%$ or more, deficit of $5.9 \%$ to $0 \%$, profit of less than $3 \%$, profit of $3 \%$ to $5.9 \%$, profit of $6 \%$ to $8.9 \%$, profit of $9 \%$ to $11.9 \%$, and profit of $12 \%$ and over.

${ }^{29}$ There may be less than 70 observations for a state within a year if none of the banks in a particular size category had profits within a particular profit range. 
(3) PROFIT RANGE $E_{i s t}=\boldsymbol{f}\left\{\beta_{1} B R A N C H_{i t-1}+\beta_{2} S T B A N K S H A R E_{i t}+\beta_{3} D E P I N S_{i}+\Sigma \gamma_{s} S I Z E_{s}\right\}$,

with observations weighted by the number of national banks in category ist. STBANKSHARE is the share of commercial banks that are state chartered, DEPINS is a dummy variable indicating whether a state had a deposit insurance system, and YEAR and SIZE are time and size dummies, respectively. $B R A N C H$ is one of our two measures of the extent of branching. In Table $8, B R A N C H$ is the ratio of branch offices to total bank offices of state and national banks in 1922 and in Table $9 B R A N C H$ is the change in this branching ratio between 1922 and 1925 .

Tables 8 and 9 show that banks located in states with relatively more branching activity had declining profitability over the period 1926-30, suggesting that there was more competition in branch banking states. ${ }^{30}$ A higher initial level of branching or a more significant expansion of branching in the early 1920s is found to have reduced profitability as competitive forces unleashed by branching likely eliminated the geographic monopolies enjoyed by unit banks and state banking systems moved toward a new equilibrium. This is shown in Tables 8 and 9 by the shift in the coefficient on branching from positive in the beginning of the sample period to negative by the end of the period. Depending on which measure of $B R A N C H$ we use, the effect on profits from branching turns negative in 1927 or 1928 and is significantly so starting in 1929. Using the 1929 regression, a one-standard-deviation increase in the ratio of branch offices to total offices or a one-standard-deviation increase in the growth of branching reduces the probability of being in a higher profit category by 4 to 7 percent.

As a robustness check, we also considered a pooled regression specification (which includes year dummies) over the sample period 1926-30, and find that states with

\footnotetext{
${ }^{30}$ Calomiris and Ramirez (2002) also find that states that prohibited branching had higher profit levels. They attribute this partly to the ability of unit banks to exert monopoly power and partly to the higher level of risk that being an undiversified unit bank would entail.
} 
relatively more branching activity had lower profits (Table 10). We use our same measure of the extent of branch banking, but lag it one year. A one-standard-deviation increase in the ratio of branch offices to total bank offices reduces the probability of being in a higher profit category by about 3 percent. While this overall effect is not terribly large, it masks different effects for different size banks. A one-standard-deviation increase in the ratio of branch offices to total bank offices for small banks, which seem to have been most affected by branching activity, reduced the probability of being in a higher category by 20 percent. For the largest banks, the probability of being in a higher category was reduced 10 percent. There seems to have been little effect on the profitability of mid-size banks. The other coefficients are as expected. Larger banks were more profitable, and the years 1929 and 1930 were particularly bad years for bank profitability.

The shift from positive profits to negative profits in later years suggest that the banking system was being transformed by the consolidation that branch banking brought with it. Our findings are consistent with studies of recent banking deregulation such as Amel and Liang (1997) and Berger, Kashyap, and Scalise (1995), who view the removal of geographic restrictions as likely reducing the exercise of market power (by unleashing more actual or potential customers into local markets) and improving allocative efficiency (by enabling resources to flow more easily toward activities that yielded higher returns and more efficient producers).

\section{Branch Banking and Financial Stability}

We now examine whether branch banking is responsible for lower national bank failures in the 1920s and 1930s. We consider two ways that branching may have reduced the incidence of failures: (1) by improving diversification opportunities through geographical expansion and (2) by weeding out weak banks via the process of 
competition. We use the same data from the Federal Reserve that was used to examine bank profitability. Since the dependent variable we use is the number of failures, we estimate the regressions using count data analysis.

We first verify that we are able to replicate the state-level results of Wheelock (1995) and Mitchener (2000a, 2004). We aggregate the size categories into state level observations and regress the number of failures of national banks in a state on variables indicating whether the state allowed branching, year dummies, and (log) number of banks in the state. ${ }^{31}$ (We also include a specification that uses the extent of branching as an independent variable.) The results shown in Table 11 match the previous literature and indicate that states permitting branch banking had fewer bank failures from 1927-1930, the period where the profits regressions suggest that competition was most important.

We now explore whether the lower number of failures from widespread branch banking was due to increased competition, diversification, or both. To conduct this test, we develop proxies for the competition and diversification effects of branch banking by taking advantage of the bifurcated nature of the U.S. banking system. To proxy how branch banking could lower failures by increasing consolidation, we compute the ratio of the branches of state banks to total bank offices in the state (COMPETITION). In states where this ratio is larger, national banks will be competing with more bank offices that are the direct result of statewide branching. And since this variable is based on the expansion of state-chartered branching, it excludes any benefits to national banks from greater diversification opportunities. To proxy for the diversification effects of branching on national banks, we compute both the percentage of national banks with branches (DIVERSIFY1) as well as ratio of national bank branches to national banks (DIVERSIFY2). In states where DIVERSIFY1 is larger, more national banks will have

\footnotetext{
${ }^{31}$ We use a pooled sample. Following Bertrand, Duflo, and Mullainathan (2002), we adjust the standard errors for the fact that there are multiple observations for each state by clustering at the state level. In states where the de jure situation differed from the de facto situation (such as West Virginia, where the laws allowed branching but the state banking commissioner refused all applications for establishing branches) or where states do not have a law, the de facto situation is used.
} 
greater opportunities to diversify their portfolios across branch offices in the state. DIVERSIFY2 captures the extent to which national banks can diversify. Mathematically, these ratios are:

(4) COMPETITION $=\quad$ Branches of state banks

Bank and branch offices of state and national banks

(5) DIVERSIFY1 =

Number of national banks with branches

Number of national banks

(6) DIVERSIFY2 =

Branches of national banks

Number of national banks

Including these measures side-by-side in regressions will allow us to identify which channel was quantitatively more important in lowering national bank failures. We use the 1922 values for all three of theses ratios in order to ensure that they are plausibly exogenous.

For state $i$, year $t$, and size category $s$, we estimate the total national bank failures (FAILURE) by the following function:

(7) FAILURE $_{i s t}=\boldsymbol{f}\left\{\beta_{1}\right.$ COMPETITION $_{i t-1}+\beta_{2}$ DIVERSIFY $_{i t-1}+\beta_{4}$ DEPINS $_{i}+\beta_{5}$ BANKS $_{i t}$

$$
+\beta_{4} \text { BUSFAIL }_{i t-1}+\beta_{5} \text { FARMFAI }_{i-1}+\beta_{6} \text { HERF }_{t}+\Sigma \theta_{\mathrm{i}} \text { YEAR }_{t}
$$$$
\left.+\Sigma \gamma_{s} S I Z E_{s}\right\}
$$

where COMPETITION and DIVERSIFY are lagged, and DIVERSIFY is one of the two measures of diversification defined above (DIVERSIFY1 or DIVERSIFY2). Since our dependent variable is disaggregated by size, we are also able to include bank size indicators (SIZE) as additional conditioning variables - a factor that has been associated 
with the probability of failure in previous studies (Calomiris and Mason 2000, Carlson 2004, White 1984). ${ }^{32}$ Figure 4 shows the distribution of banks and failures by bank size category. To control for differences in real shocks across states, we include a measure of lagged business failures $(B U S F A I L)$ and compute agricultural distress as the lagged farm failure rate $(F A R M F A I L)$. We control for additional state level factors: the (log) number of national banks $(B A N K S)$; the Herfindahl index $(H E R F)$, described above; and whether a state had a deposit insurance system (DEPINS). ${ }^{33}$ All 48 states are used and we include year dummies to capture any time specific influences. Since each size category provides a unique observation, we have 10 observations for each state for each year.

Since our profit regressions suggest that the initial shakeout and consolidation process had taken place by the end of 1926, we pool our data over the period 1927-30, and estimate equation (7) using count data analysis with a negative binomial distribution. ${ }^{34}$ However, because we observe each state multiple times, we cluster our standard errors as suggested by Bertrand, Duflo, and Mullainathan (2004). ${ }^{35}$

The relative effects of competition and diversification in producing lower failures rates in states allowing branch banking are shown in Tables $12 .{ }^{36}$ The negative and statistically significant estimated coefficient on our ratio that proxies for competition supports the hypothesis that branch banking improves financial stability by weeding out

\footnotetext{
${ }^{32}$ Larger banks may be more stable because of their greater ability to spread risks and coordinate emergency assistance with other banks and their reduced propensity to spread contagion when the banking sector is subjected to external shocks.

${ }^{33} \mathrm{We}$ include the deposit insurance indicator variable for two reasons. First, the presence of deposit insurance in eight states has been linked to higher failure rates in the 1920s in these states (Wheelock 1992, Wheelock and Wilson 1995, and Calomiris 1990). Moreover, increased competition can potentially exacerbate the moral hazard problem associated with deposit insurance (Keeley 1990, Demzetz, Saidenberg and Strahan 1996, Hellman and Stiglitz 2000, Dick 2002, and Bergstresser 2002). There is however, little overlap between states that allowed branching and state that had a deposit insurance program.

${ }^{34} \mathrm{~A}$ few states have less than 10 observations per year because no banks exist in some size categories.

${ }^{35}$ As an alternative, we estimated a panel regression with state-level fixed effects and found similar effects.

${ }^{36}$ Branching and bank size are generally correlated, and both allow a bank to diversify: size allows the bank to make more total loans and branching permits the bank to make loans in different locations. In this analysis, we focus on the geographic diversification allowed by branching and control for bank size by including dummies for the size group of the bank. Another way of controlling for bank size is by repeating this regression using only banks of a particular size group. These regressions yield similar results to those shown here.
} 
inefficient banks through increased competition and consolidation. Increased competition stemming from branching significantly reduces failures. An increase in the competition ratio of 0.1 (about one standard deviation) results in a 35 percent decrease in the number of failures in a state. On the other hand, we find no evidence that either of our measures for diversification resulting from branching is associated with fewer national bank failures, where column 1 of Table 12 uses DIVERSIFY1 (the percent of national banks with branches) and column 2 uses DIVERSIFY2 (average branches per national bank).

These results do not appear to be sensitive to choosing a different measure of the extent of branching. As a sensitivity test, we use one-year lagged values of COMPETITION, DIVERSIFY1, and DIVERSIFY2. Here again, the sign on COMPETITION is negative and statistically significant. We find no evidence that either of our measures for diversification resulting from branching is associated with fewer national bank failures; indeed, the only statistically significant coefficient for either of the diversification measures has the wrong expected sign. It should be noted however, that these results do not provide any indication about the importance of diversification through branching at state banks, where the bulk of the banking systems' branches were located.

The signs on the other explanatory variables in the failure regressions are largely as expected. Bank failures were significantly higher in 1929 and 1930 (as a result of the Depression). An increase in the banks at risk boosts failures. And consistent with the research using individual bank data from this period, larger banks were less likely to fail and smaller banks were more likely to fail. ${ }^{37}$ After controlling for other factors, farm failure rates and deposit insurance were statistically insignificant.

\footnotetext{
${ }^{37} \mathrm{We}$ also tested an alternative hypothesis that branching decreases failures by facilitating a substitute to failure, namely merging with another bank. (We thank Joe Mason for suggesting this idea.) According to this view, branching reduces failures because it facilitates mergers by expanding the pool of possible merger partners from banks within the city to all state banks within the state. We test this hypothesis by constructing an index of the ease with which banks might merge. This index is the number of mergers divided by the total number of bank exits (mergers, failures, and voluntary liquidations). However, we do not find a significant relationship between this measure and the number of failures.
} 
California had by far the most branches, about 660 in 1926. New York had the second most with approximately 489 branches. As a test of the robustness of our results, we eliminate California from the sample and repeat the estimation. As Table 14 shows, the results are similar in terms of the effects that the two channels had on failures. Interestingly, both the size of effect of competition and its significance are greater when California is excluded from the sample. The same size increase in the ratio of branches of state banks to total bank offices (again about one-tenth of a standard deviation) now reduces the number of failures by about 60 percent. The reported coefficients on the other variables are quite similar to those shown in the previous table.

To check the sensitivity of our results to the choice of stability measures, we also considered an alternative dependent variable - the share of assets at national banks affected by failures. The results (not reported) are similar to what is displayed in Tables 10 and 11. States with more extensive state branching had a smaller share of assets located in failing national banks.

\section{Section 5. Conclusion}

This paper revises our understanding of the role that branching played in improving the stability of banking systems during the 1920s and 1930s. Diversification was not the primary channel through which branch banking made state banking systems more resistant to shocks. Instead, the expansion of statewide branch banking induced greater competition in states where it was permitted and improved the stability of their banking systems by removing weak and inefficient banks. Our results are largely consistent with recent literature that has examined the effects of deregulation in other settings. Like Amel and Liang (1997), who examine banks and branching in the 1980s, and Classens, Demirguc-Kunt, and Huizinga (1998), who look at banks expanding internationally, we find that the growth of branch banking in the 1920s is associated with 
lower profits in the latter part of the decade. Our results put the well-documented response of unit bankers (particularly those located in rural areas) to the growth of branch banking in the 1920 s in proper perspective. Because the growth of statewide branching was eroding the monopoly profits that unit bankers had previously enjoyed, they responded (as predicted by the economic theory of regulation) by lobbying state and federal governments to legally limit it from spreading. As a result of their influence, many states consequently continued to prohibit branching during the 1920 s.

Similar to what Jayaratne and Strahan (1998) and Stiroh and Strahan (2003) find for the branching deregulation of the 1980s, we find that this more competitive atmosphere is associated with a higher exit rate. This confirms what some economic historians have suggested, but not shown. As White (1985, p.291) contends, "The number of small banks in rural areas needed to be reduced, and the mergers assisted the weaker institutions with less pain than the massive failures that followed. Unfortunately, this development was stifled by regulations in most states that forbade branch banking." The market upheaval and increase in competition resulting from the removal of legal barriers to entry, however, resulted in longer-run stability, with fewer failures in states where branching had spread. Our results also confirm the hypothesis of Berger, Demsetz, and Strahan (1999), that competition prompts weaker banks to leave the banking system, and parallels the findings of Kaminsky and Schmuckler (2002), that international financial liberalization causes some initial turbulence in financial markets but over time results in reduced volatility. 


\section{References:}

Allen, Franklin and Douglas Gale. (2000). Comparing Financial Systems. Cambridge, MA: MIT Press.

Alston, Lee, Wayne Grove, and David Wheelock. (1994). "Why Do Banks Fail?

Evidence from the 1920s." Explorations in Economic History, Vol. 31, pp. 409-31.

Amel, Dean and J. Nellie Liang. (1997). "Determinants of Entry and Profits in Local Banking Markets.” Review of Industrial Organization, Vol. 12, pp. 59-78.

Berger, Allen, Rebecca Demsetz, and Phillip Strahan. (1999). "The consolidation of the Financial Services Industry: Causes, Consequences, and Implications for the Future." Journal of Banking and Finance, Vol. 23, pp. 135-194.

Berger, Allen and Timothy Hannan. (1998). "The Efficiency Cost of Market Power in the Banking Industry: A Test of the 'Quiet Life' and Related Hypotheses." The Review of Economics and Statistics, Vol. 80(3), pp. 454-65.

Berger, Allen, Anil Kashyap, and Joseph Scalise. (1995). "The Transformation of the U.S. Banking Industry: What a Long, Strange Trip It's Been." Brookings Papers on Economic Activity, Issue 2, pp. 55-218.

Bertrand, Marianne, Esther Duflo, and Sendhil Mullainathan. (2004). "How Much Should We Trust Differences-in-Differences Estimates?" Quarterly Journal of Economics, Vol.119(1), pp.249-75.

Calomiris, Charles. (2000). U.S. Bank Deregulation in Historical Perspective. Cambridge: The Cambridge University Press.

Calomiris, Charles. (1992). "Do 'Vulnerable' Economies Need Deposit Insurance? Lessons from U.S. Agriculture in the 1920s." In If Texas Were Chile: A Primer on Banking Reform Philip Brock (ed.), San Francisco, CA: Institute for Contemporary Studies, pp. 237-349.

Calomiris, Charles. (1990). "Is Deposit Insurance Necessary? A Historical Perspective." Journal of Economic History Vol. 50(2), pp. 283-95.

Calomiris, Charles and Joseph Mason. (2000). "Causes of U.S Bank Distress During the Depression.” NBER Working Paper 7919.

Calomiris, Charles and Carlos Ramirez. (2002). "The Political Economy of Bank Entry Restrictions: Theory and Evidence from the U.S. in the 1920s." Unpublished manuscript.

Cameron, A. Colin and Pravin Trivedi. (1998). Regression Analysis of Count Data. Cambridge: The Cambridge University Press. 
Carlson, Mark. (2004). “Are Branch Banks Better Survivors? Evidence from the Depression Era.” Economic Inquiry Vol. 42(1), pp. 111-126.

Chapman, John and Ray Westerfield. (1942). Branch Banking: Its Historical and Theoretical Position in America and Abroad. New York: Harper and Brothers Publishers.

Cherin, Antony and Ronald Melicher. (1988). "Impact of Branch Banking on Bank Firm Risk via Geographic Market Diversification.” Quarterly Journal of Business and Economics Vol. 27(2), pp. 73-95.

Claessens, Stijn, Asli Demirguc-Kunt, and Harry Huizinga. (2001). "How Does Foreign Entry Affect the Domestic Banking Market?” Journal of Banking and Finance, Vol. 25(5), pp. 891-911.

Comptroller of the Currency. (various years). Annual Report. Washington, DC: United States Government Printing Office.

Comptroller of the Currency. (various years). Statements of National Banks. Washington, DC: United States Government Printing Office.

Demsetz, Rebecca S. and Philip E. Strahan (1997). "Diversification, Size, and Risk at Bank Holding Companies," Journal of Money, Credit and Banking 29(3), pp. 300-13.

DeYoung, Robert, Iftekhar Hasan, and Bruce Kirchhoff. (1998). "The Impact of Out-ofState Entry on the Cost Efficiency of Local Commercial Banks." Journal of Economics and Business, Vol. 22(5), pp. 191-203.

Drummond, Ian. (1991). "Why Canadian Banks Did Not Collapse in the 1930s." In The Role of Banks in the Interwar Economy, edited by James, et al. Cambridge: Cambridge University Press.

Economides, Nicholas, R. Glenn Hubbard, and Darius Palia. (1996). “The Political Economy of Branching Restrictions and Deposit Insurance: A Model of Monopolistic Competition Among Small and Large Banks." Journal of Law and Economics, Vol. 39(2), pp. 667-704.

Federal Reserve Board of Governors. (1943). Banking and Monetary Statistics. Washington, DC: The National Capital Press.

Federal Reserve Board of Governors. (1931). Report of the Branch, Chain, and Group Banking Committee Volumes 2 and 9. Washington, DC: Board of Governors.

Friedman, Milton and Anna Schwartz. (1963). A Monetary History of the United States, 1867-1960. Princeton, NJ: Princeton University Press. 
Gart, Alan. (1994). Regulation, Deregulation, Reregulation. New York: John Wiley and Sons, Inc.

Grossman, Richard. (1994). “The Shoe That Didn't Drop: Explaining Banking Stability in the Great Depression." Journal of Economic History, Vol. 54, pp. 654-82.

Hubbard, R. Glenn. (1994). Money, the Financial System, and the Economy. Reading, MA: Addison-Wesley Publishing Company.

Folkerts-Landau, David and Carl-Johan Lindgren. (1998). Toward a Framework for Financial Stability. Washington, DC: International Monetary Fund.

Kaminsky, Graciela, and Sergio Schmukler. (2002). "Short-Run Pain, Long-Run Gain: The Effects of Financial Liberalization.” World Bank Working Paper Series 2912.

Jayaratne, Jith, and Philip E. Strahan. (1998). "Entry Restrictions, Industry Evolution, and Dynamic Efficiency: Evidence from Commercial Banking." Journal of Law and Economics, Vol.41, pp. 239-73.

Koskela, Erkki and Rune Stenbacka. (2000). "Is There a Tradeoff Between Bank Competition and Financial Fragility?" Journal of Banking and Finance. Vol. 24, pp. 1853-73.

Kroszner, Randall and Phillip Strahan. (2000). "Obstacles to Optimal Policy: The Interplay of Politics and Economics in Shaping Bank Supervision and Regulation Reforms.” NBER Working Paper 7582.

Kroszner, Randall and Phillip Strahan. (1998). "What Drives Deregulation? Economics and Politics of the Relaxation of Bank Branching Restrictions." Quarterly Journal of Economics, Vol. 114(3), pp. 1437-67.

Kryzanowski, Lawrence and Gordon Roberts. (1993). "Canadian Banking Solvency." Journal of Money, Credit and Banking, Vol. 25, pp. 361-76.

Lauch, Louis and Neil Murphy. (1970). "A Test of the Impact of Branching on Deposit Variability." Journal of Financial and Quantitative Analysis (September), Vol. 5, pp. 323-7.

Levine, Ross. (1996). "Foreign Banks, Financial Development, and Economic Growth." In International Financial Markets: Harmonization versus Competition, edited by Claude Barfield. Washington, DC: AEI Press, pp. 224-54.

Matutes, Carmen and Xavier Vives. (2000). "Imperfect Competition, Risk Taking, and Regulation in Banking.” European Economic Review, Vol. 44, pp. 1-34. 
Mitchener, Kris. (2000a). "Do Supervision and Regulation Influence Financial Stability? Evidence from the Great Depression." Unpublished manuscript, University of California, Berkeley.

Mitchener, Kris. (2004). "Bank Supervision, Regulation, and Instability During the Great Depression.” NBER Working Paper 10475.

Mitchener, Kris. (2000c). "Regulatory Chaos and the Great Depression: The Evolution of State Bank Regulation.” Unpublished manuscript, University of California, Berkeley.

Morgan, Donald, Rime, Bertrand, and Philip E. Strahan. (2003). "Bank Integration and State Business Cycles.” NBER Working Paper 9704.

Polk's Bankers Encyclopedia Co. (various years). Polk's Bankers Encyclopedia. Detroit, MI: Polk’s Bankers Encyclopedia Co.

Preston, Howard. (1928). "Recent Developments in Branch Banking." American Economic Review, Vol. 14, pp. 443-62.

Southworth, Shirley. (1928). Branch Banking in the United States, New York: McGrawHill Book Company.

Sprague, Oliver M.W. (1903). "Branch Banking in the United States.” Quarterly Journal of Economics, Vol. 27, pp. 242-60.

Stiroh, Kevin J.and Philip E. Strahan. (2003). "Competitive Dynamics of Deregulation: Evidence from U.S. Banking." Journal of Money, Credit, and Banking, Vol. 35, pp.80128.

Study Commission for Indiana Financial Institutions. (1932). Report. Indianapolis, IN: Seventy-Seventh General Assembly.

Tippetts, Charles S. (1929). State Banks and the Federal Reserve System. New York: D. Van Nostrand Company.

U.S. Department of Agriculture. (1936). Circular No. 414 Farm Bankruptcies, 18981935. Washington, DC: U.S. Department of Agriculture.

U.S. Department of Commerce. (various years). Statistical Abstract of the United States. Washington, DC: GPO.

Wacht, Richard. (1968). "Branch Banking and Risk." Journal of Financial and Quantitative Anaylsis, Vol. 3 (March), pp. 97-107. 
Wheelock, David. (1995). "Regulation, Market Structure, and the Bank Failures of the Great Depression." Federal Reserve Bank of St. Louis Review, Vol. 77, pp. $27-38$.

Wheelock, David. (1993). "Government Policy and Banking Market Structure in the 1920s.” Journal of Economic History, Vol. 53(4), pp. 857-879.

Wheelock, David (1992). "Regulation and Bank Suspensions: New Evidence from the Agricultural Collapse of the 1920s." Journal of Economic History, Vol. 52, pp.806-25.

Wheelock, David and Paul Wilson. (2000). "Why do Banks Disappear? The Determinants of U.S. Bank Failures and Acquisitions." Review of Economics and Statistics, Vol. 82(1), pp. 127-38.

Wheelock, David and Paul Wilson. (1995). "Explaining Bank Failures: Deposit Insurance, Regulation, and Efficiency." The Review of Economics and Statistics, Vol.77(4), pp.689-700.

White, Eugene. (1985). “The Merger Movement in Banking, 1919-33." Journal of Economic History, Vol. 45(2), pp. 285-91.

White, Eugene. (1984). "A Reinterpretation of the Banking Crises of 1930." Journal of Economic History, Vol. 44, pp. 119-138.

White, Eugene. (1983). "State-Sponsored Insurance of Bank Deposits in the United States, 1907-1929.” Journal of Economic History, Vol. 41(3), pp. 537-57.

White, Eugene. (1983). The Regulation and Reform of the American Banking System, 1900-1929. Princeton, NJ: Princeton University Press. 
Figure 1

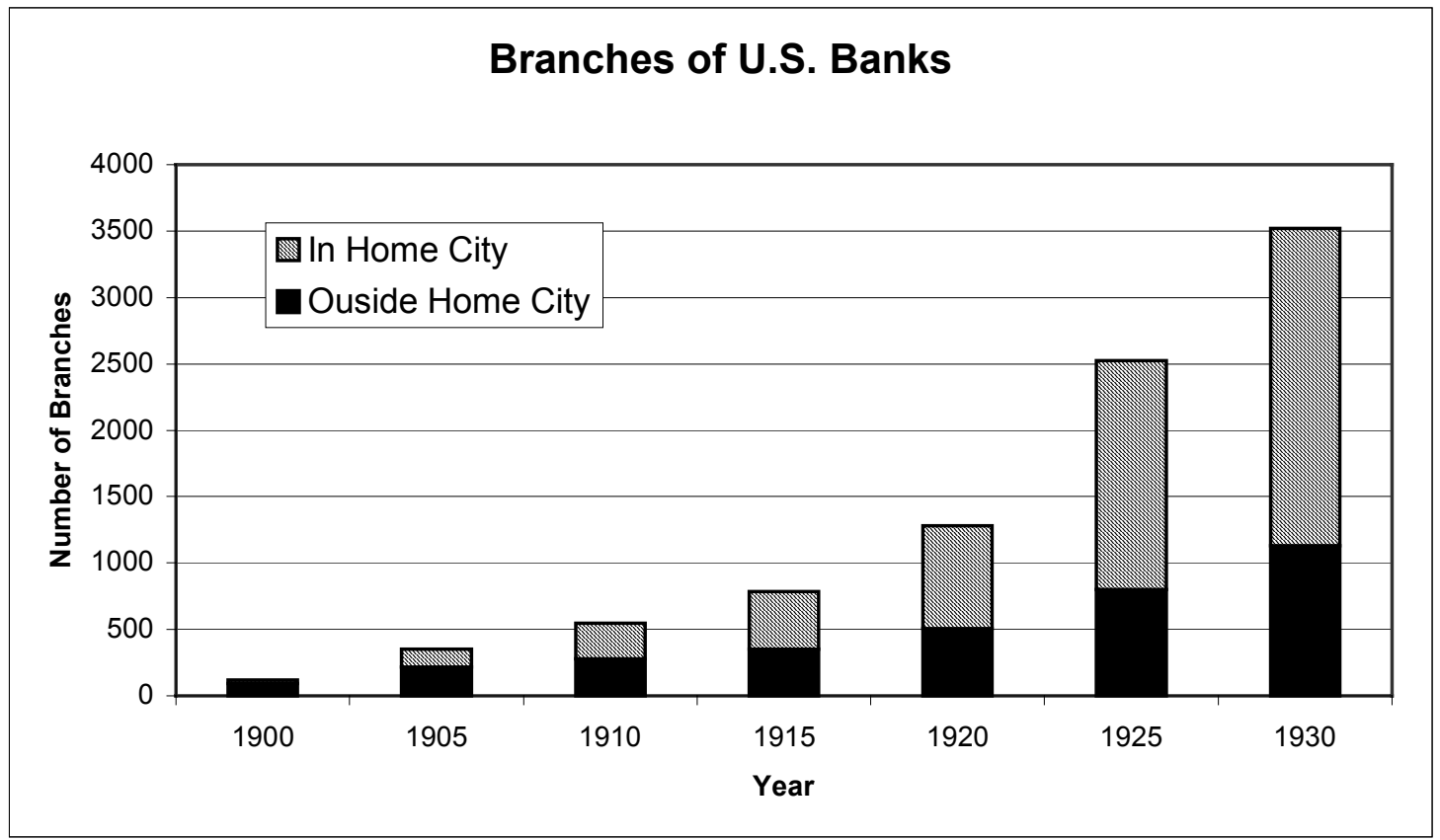

Sources and notes: Federal Reserve Board (1931), vol. 2. Home city indicates branches located in the same city as the bank's headquarters.

Figure 2

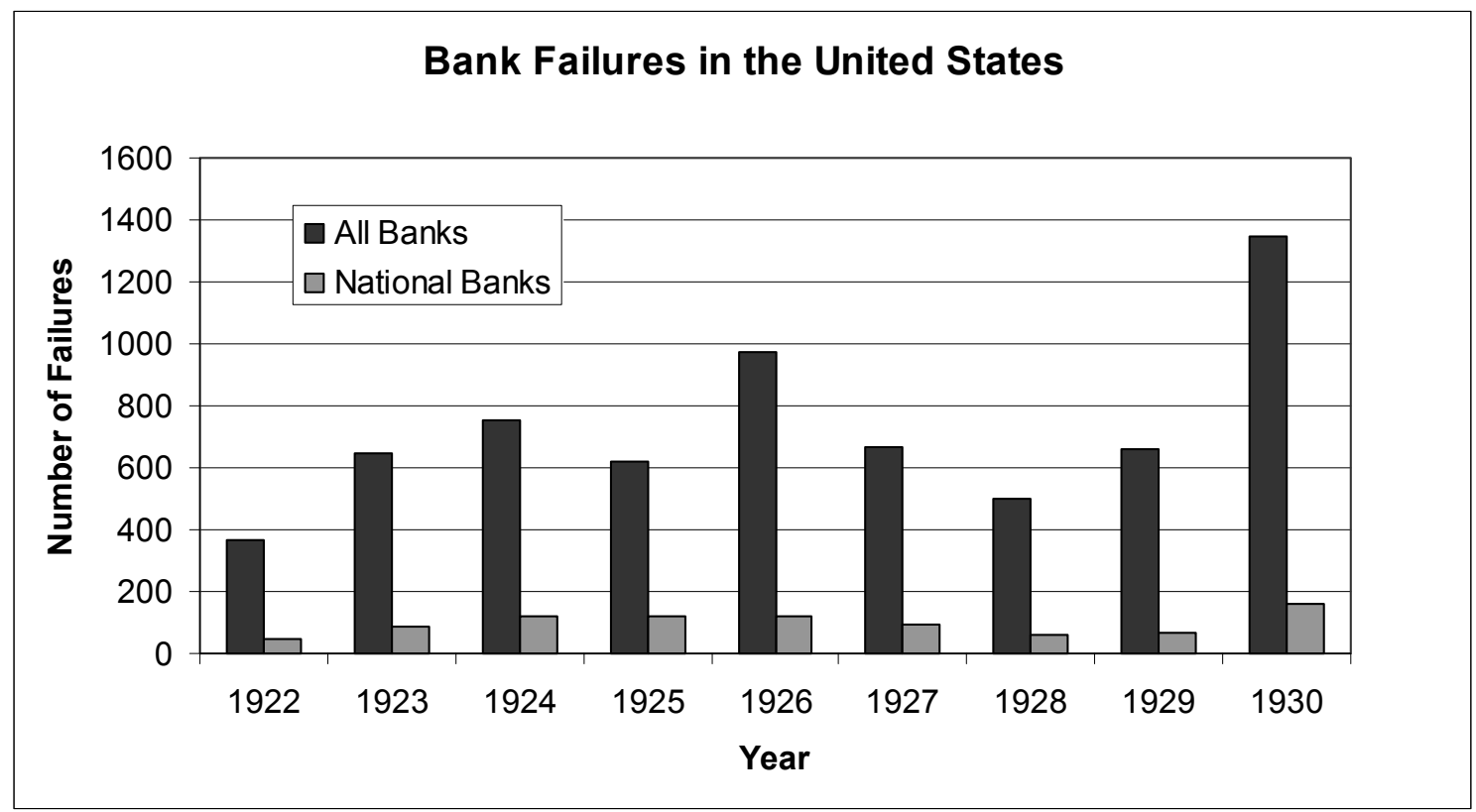

Source: Federal Reserve Board (1943). 
Figure 3 - Branches of National and State Banks outside the City of the Home Office (December 31, 1931)

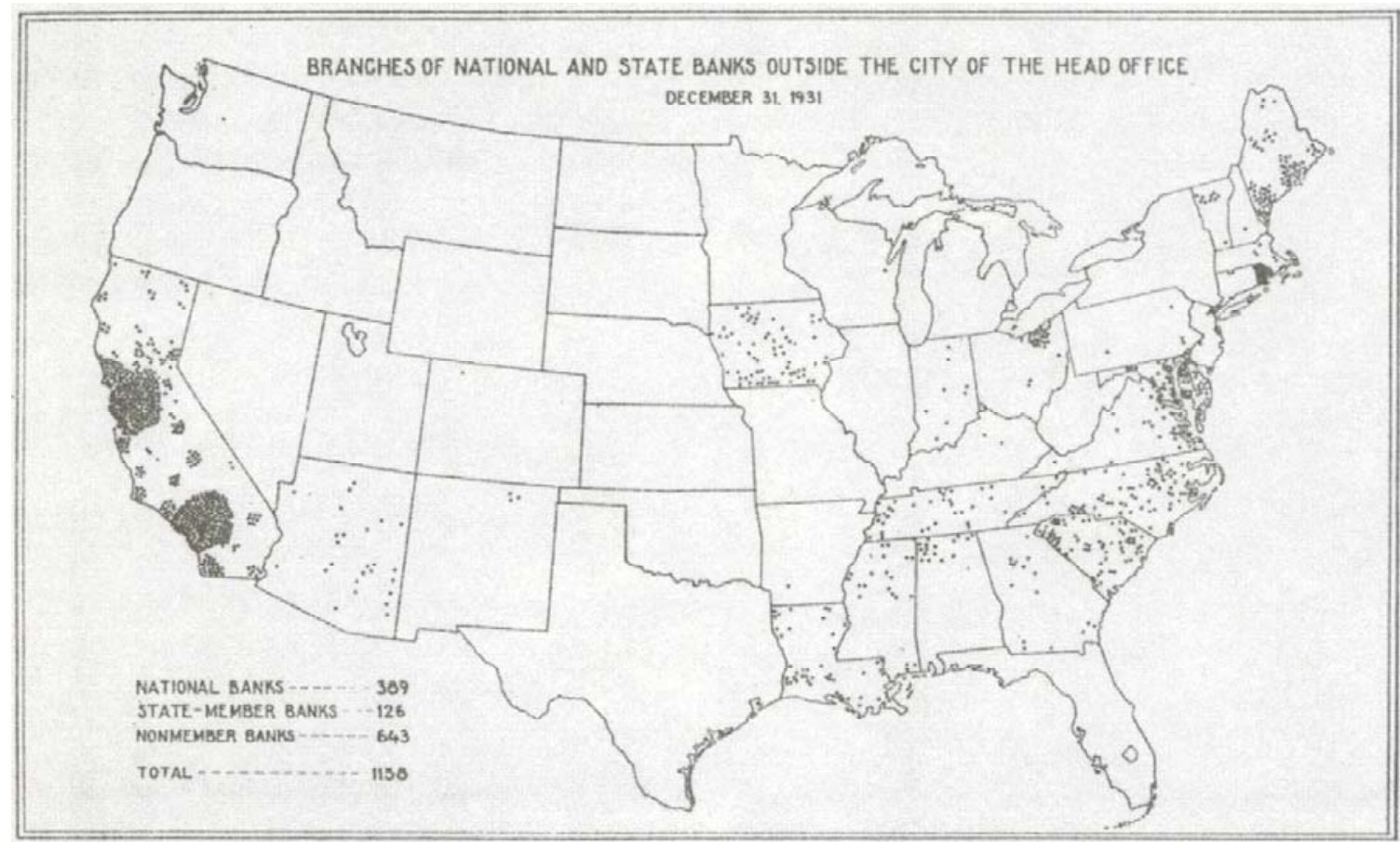

Source: Federal Reserve Board (1931, Vol. 2, p.17).

Note: In California there are numerous branches in the metropolitan areas centering around San Francisco and Los Angeles, but technically outside their city limits. On the map the dots extend considerably beyond the territory in which the branches are actually located around these cities. 
Figure 4 - Annual Average Number of National Banks and Bank Failures by Size Category

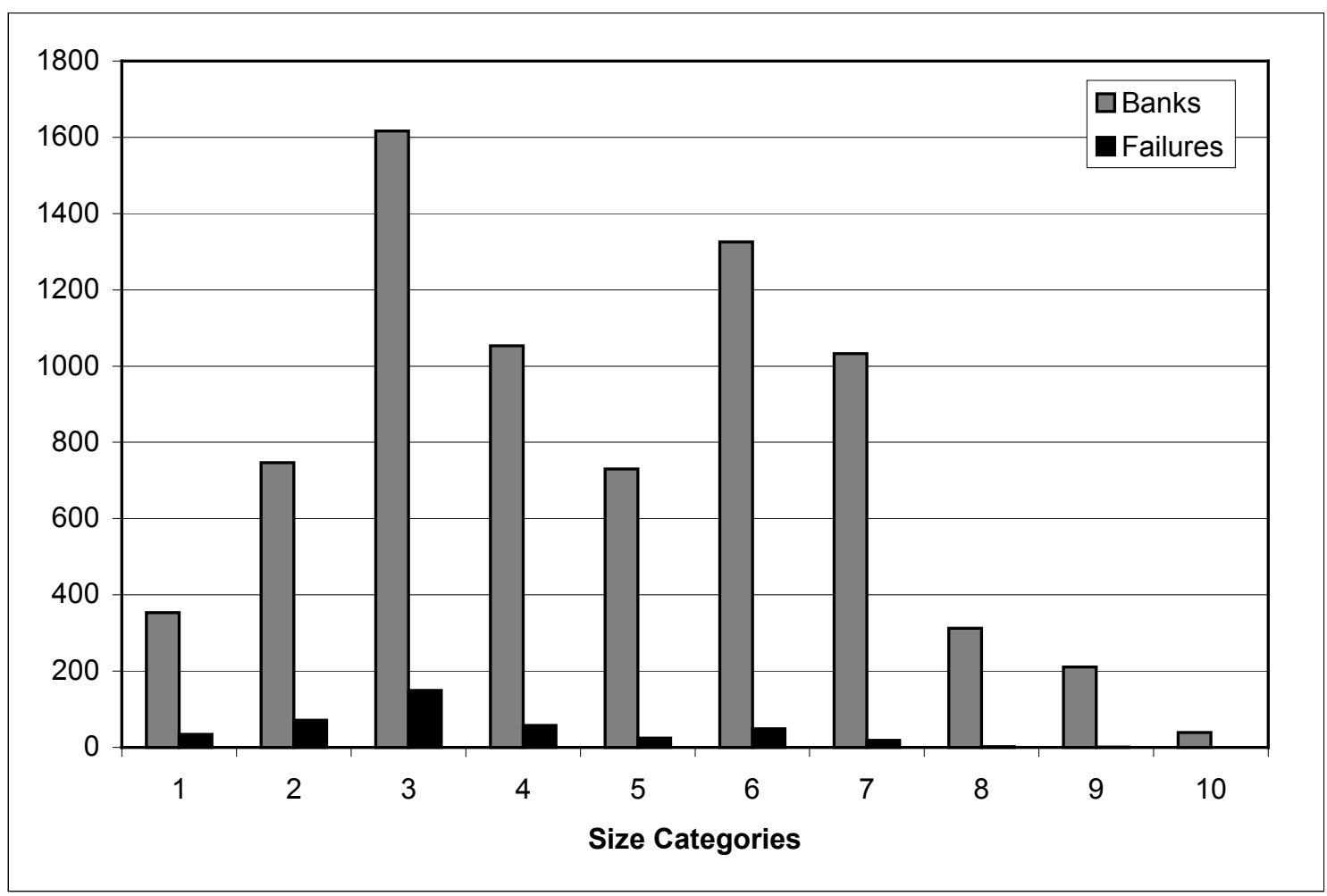

Sources and Notes: Comptroller of the Currency (various years) and Federal Reserve Board (1931). Annual averages are constructed over the period 1926-1930. Size categories are: category 1 - under $\$ 150,000$; category 2 - $\$ 150,000-\$ 250,000$; category 3 - $\$ 250,000-\$ 500,000$; category 4 - $\$ 500,000-\$ 750,000$; category 5 - $\$ 750,000-\$ 1,000,000$; category 6 - $\$ 1,000,000-\$ 2,000,000$; category 7 - $\$ 2,000,000$ $\$ 5,000,000$; category 8 - $(\$ 5,000,000-\$ 10,000,000$; category 9 - $\$ 10,000,000-\$ 50,000,000$; category 10 $\$ 50,000,000$ and over. 
Table 1 - The Distribution of Bank Branches by Town Population (1931)

\begin{tabular}{|l|r|r|r|r|r|r|}
\hline & \multicolumn{2}{|c|}{$\begin{array}{c}\text { Branches Outside } \\
\text { Home-Office City }\end{array}$} & $\begin{array}{r}\text { Branches Inside Home- } \\
\text { Office City }\end{array}$ & \multicolumn{2}{|c|}{ All Branches } \\
\hline Town Population & Number & $\begin{array}{c}\text { Percent of } \\
\text { Total }\end{array}$ & Number & $\begin{array}{c}\text { Percent of } \\
\text { Total }\end{array}$ & Number & $\begin{array}{c}\text { Percent of } \\
\text { Total }\end{array}$ \\
\hline Under 500 & 189 & 16.32 & 2 & 0.09 & 191 & 5.73 \\
$500-1,000$ & 173 & 14.94 & 0 & 0.00 & 173 & 5.19 \\
$1,000-2,500$ & 207 & 17.88 & 7 & 0.32 & 214 & 6.42 \\
$2,500-5,000$ & 134 & 11.57 & 7 & 0.32 & 141 & 4.23 \\
$5,000-10,000$ & 107 & 9.24 & 9 & 0.41 & 116 & 3.48 \\
$10,000-25,000$ & 91 & 7.86 & 27 & 1.24 & 118 & 3.54 \\
$25,000-50,000$ & 46 & 3.97 & 63 & 2.90 & 109 & 3.27 \\
$50,000-100,000$ & 60 & 5.18 & 132 & 6.07 & 192 & 5.76 \\
$100,000+$ & 151 & 13.04 & 1929 & 88.65 & 2080 & 62.39 \\
& 1158 & 100 & 2176 & 100 & 3334 & 100 \\
\hline Total & & & & & \\
\hline
\end{tabular}

Source: Federal Reserve Board (1931), vol. 2.

Table 2 - Summary Statistics for National Banks

\begin{tabular}{|c|c|c|c|c|c|c|c|c|c|c|c|}
\hline & & 1922 & 1923 & 1924 & 1925 & 1926 & 1927 & 1928 & 1929 & 1930 & Average \\
\hline \multirow{5}{*}{$\begin{array}{c}\text { Unit } \\
\text { Banking }\end{array}$} & Number of states & 30 & 30 & 28 & 28 & 28 & 29 & 30 & 29 & 28 & 29 \\
\hline & $\begin{array}{l}\text { Average number of } \\
\text { banks }\end{array}$ & 175.8 & 173.2 & 165.8 & 165.6 & 155.4 & 147.6 & 143.3 & 142.3 & 138.2 & 157.9 \\
\hline & $\begin{array}{l}\text { Average voluntary } \\
\text { liquidation rate }\end{array}$ & 14 & 17 & 18 & 24 & 17 & 20 & 27 & 25 & 47 & \\
\hline & Aver & 1.2 & 2.0 & 1.8 & 2.2 & 1.9 & 2.3 & 2.2 & 3.5 & 4.0 & 2.1 \\
\hline & $A v$ & 2.4 & 1.8 & 1.5 & 2.3 & 1.9 & 1.2 & 1.3 & 2.3 & 2.2 & 1.9 \\
\hline \multirow{5}{*}{$\begin{array}{c}\text { Allows } \\
\text { Some Form } \\
\text { of } \\
\text { Branching }\end{array}$} & Num & 18 & 18 & 20 & 20 & 20 & 19 & 18 & 19 & 20 & 19 \\
\hline & $\begin{array}{l}\text { Average number of } \\
\text { banks }\end{array}$ & 168.6 & 169.1 & 171.6 & 172.9 & 167.3 & 172.8 & 176.7 & 165.9 & 157.5 & 169.1 \\
\hline & $\begin{array}{l}\text { Average voluntary } \\
\text { liquidation rate }\end{array}$ & & & 26 & 16 & 34 & 0 & 28 & 40 & 40 & 26 \\
\hline & Avera & 1.4 & 1.6 & 2.6 & 1.2 & 2.8 & 2.2 & 3.1 & 4.4 & 3.8 & 2.4 \\
\hline & Average entry rate & 2.6 & 1.9 & 2.5 & 2.5 & 1.8 & 1.2 & 1.5 & 2.0 & 0.8 & 1.9 \\
\hline
\end{tabular}

Sources and Notes: Rates are computed using data from the Annual Report of the Comptroller of the Currency (1922-1930). Rates are expressed as percentages of existing banks. Within-category rates are unweighted averages of state rates. The last column shows the average of the yearly observations over the entire sample period, 1922-1930. 
Table 3 - Effect of Initial Level of Branching on Voluntary Liquidations, Mergers, and Entry

Dependent variable: The average count of voluntary liquidations, mergers, and entries of national banks in a state for the period 1923-1930.

\begin{tabular}{|c|c|c|c|}
\hline & $\begin{array}{l}\text { Average Voluntary } \\
\text { Liquidations }\end{array}$ & Average Mergers & $\begin{array}{l}\text { Average New } \\
\text { Banks }\end{array}$ \\
\hline Intercept & $\begin{array}{l}-6.80 * * * \\
(1.17)\end{array}$ & $\begin{array}{l}-6.77 * * * \\
(1.16)\end{array}$ & $\begin{array}{l}-4.63 * * * \\
(1.09)\end{array}$ \\
\hline $\begin{array}{l}\text { Ratio of Branches to Total } \\
\text { Bank Offices (1922 Value) }\end{array}$ & $\begin{array}{l}5.02 * * * \\
(1.56)\end{array}$ & $\begin{array}{l}4.75 * * * \\
(1.54)\end{array}$ & $\begin{array}{l}1.47 \\
\left(\begin{array}{l}1.66) \\
\end{array}\right.\end{array}$ \\
\hline Banks Per Capita & $\begin{array}{l}0.58 * * \\
(0.23) \\
\end{array}$ & $\begin{array}{l}1.26 * * * \\
(0.18)\end{array}$ & $\begin{array}{l}1.15 * * * \\
(0.17) \\
\end{array}$ \\
\hline $\begin{array}{l}\text { Share of State Income from } \\
\text { Agriculture }\end{array}$ & $\begin{array}{l}0.03 * * \\
(0.02)\end{array}$ & $\begin{array}{l}0.04 * * \\
(0.02)\end{array}$ & $\begin{array}{c}0.00 \\
(\quad 0.02) \\
\end{array}$ \\
\hline Log Number of Banks & $\begin{array}{l}1.26 * * * \\
\left(\begin{array}{l}0.18) \\
\end{array}\right.\end{array}$ & $\begin{array}{l}1.26 * * * \\
(0.18) \\
\end{array}$ & $\begin{array}{l}1.15 * * * \\
(0.17)\end{array}$ \\
\hline Deposit Insurance & $\begin{array}{c}-0.46 \\
(\quad 0.39) \\
\end{array}$ & 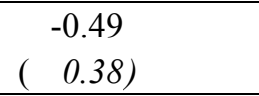 & $\begin{array}{l}0.83 * * \\
(0.40) \\
\end{array}$ \\
\hline Dispersion & $\begin{array}{r}0.12 \\
(\quad 0.08) \\
\end{array}$ & $\begin{array}{l}0.10 \\
(\quad 0.07) \\
\end{array}$ & $\begin{array}{c}0.12 \\
(\quad 0.10) \\
\end{array}$ \\
\hline $\begin{array}{l}\text { Observations } \\
\text { Log-Likelihood }\end{array}$ & $\begin{array}{c}48 \\
-96.9\end{array}$ & $\begin{array}{c}48 \\
-91.1 \\
\end{array}$ & $\begin{array}{c}48 \\
-96.1 \\
\end{array}$ \\
\hline
\end{tabular}

Note. The symbols $(* * *),(* *)$, and $(*)$ indicate statistical significance at the 1,5 , and 10 percent level, respectively. Standard errors are in parentheses. Data on voluntary liquidations, mergers, and entries of national banks are from the Annual Report of the Comptroller of the Currency (1923-1930). Population and income shares are from 1920 Census report. The log of the number of banks is the average number of national banks for 1923-1930. Branch offices and total bank offices include both state and national banks. 
Table 4 - Effect of an Increase in Branching on Voluntary Liquidations, Mergers, and Entry

Dependent variable: The average count of voluntary liquidations, mergers, and entries of national banks in a state for the period 1926-1930.

\begin{tabular}{|c|c|c|c|}
\hline & \begin{tabular}{|} 
Average Voluntary \\
Liquidations \\
$(1926-1930)$ \\
Count \\
\end{tabular} & $\begin{array}{l}\text { Average Mergers } \\
\quad(1926-1930) \\
\text { Count }\end{array}$ & $\begin{array}{l}\text { Average New } \\
\quad \text { Banks } \\
(1926-1930) \\
\text { Count }\end{array}$ \\
\hline Intercept & 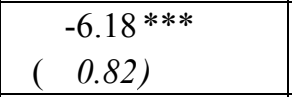 & 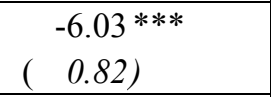 & $\begin{array}{l}-4.79 * * * \\
\left(\begin{array}{l}1.28) \\
\end{array}\right.\end{array}$ \\
\hline $\begin{array}{l}\text { Change in the Ratio of Branches to } \\
\text { Total Bank Offices (1922-1925) }\end{array}$ & $\begin{array}{l}6.62 * * * \\
(1.03) \\
\end{array}$ & $\begin{array}{l}6.66 * * * \\
(1.03) \\
\end{array}$ & $\begin{array}{r}3.15 \\
(\quad 2.48) \\
\end{array}$ \\
\hline Banks Per Capita & $\begin{array}{r}0.32 \\
(\quad 0.23) \\
\end{array}$ & $\begin{array}{l}1.19 * * * \\
(0.13) \\
\end{array}$ & $\begin{array}{l}1.13 * * * \\
(0.23) \\
\end{array}$ \\
\hline $\begin{array}{l}\text { Share of State Income from } \\
\text { Agriculture }\end{array}$ & $\begin{array}{l}0.04 * * * \\
(0.01)\end{array}$ & $\begin{array}{l}0.04 * * * \\
(0.01)\end{array}$ & $\begin{array}{c}-0.01 \\
\left(\begin{array}{c}0.02 \\
0\end{array}\right)\end{array}$ \\
\hline Log Number of Banks & $\begin{array}{l}1.21 * * * \\
(0.13) \\
\end{array}$ & $\begin{array}{l}1.19 * * * \\
(0.13) \\
\end{array}$ & $\begin{array}{l}1.13 * * * \\
(0.23) \\
\end{array}$ \\
\hline Deposit Insurance & 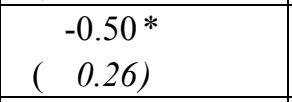 & $\begin{array}{c}-0.49 * \\
(\quad 0.26) \\
\end{array}$ & $\begin{array}{l}1.39 * * * \\
(0.50)\end{array}$ \\
\hline Dispersion & N.A.^ & N.A. $\wedge$ & $\begin{array}{l}0.26 \\
(\quad 0.17) \\
\end{array}$ \\
\hline $\begin{array}{l}\text { Observations } \\
\text { Log-Likelihood }\end{array}$ & $\begin{array}{c}48 \\
-165.9 \\
\end{array}$ & $\begin{array}{c}48 \\
-150.3 \\
\end{array}$ & $\begin{array}{c}48 \\
-48.4 \\
\end{array}$ \\
\hline
\end{tabular}

Note. The symbols $(* * *),(* *)$, and $(*)$ indicate statistical significance at the 1,5 , and 10 percent level, respectively. The symbol $\left({ }^{\wedge}\right)$ indicates that we reject overdispersion in the data and estimate the regression using a Poisson distribution. Standard errors are in parentheses. Data on voluntary liquidations, mergers, and entries of national banks are from the Annual Report of the Comptroller of the Currency (1926-1930). Population and income shares are from 1920 U.S. Census. Banks per capita is the 1920 value. The log of the number of banks is the average number of national banks for 1926-1930. Branch offices and total bank offices include both state and national banks. 
Table 5 - Effect of Branching on Voluntary Liquidations, Mergers, and Entry using a Pooled Sample

Dependent variable: The count of voluntary liquidations, mergers, and entries of national banks in a state per year.

\begin{tabular}{|c|c|c|c|}
\hline & $\begin{array}{c}\text { Voluntary } \\
\text { Liquidations } \\
(1923-1930)\end{array}$ & $\begin{array}{c}\text { Mergers } \\
(1923-1930)\end{array}$ & $\begin{array}{c}\text { New Banks } \\
(1923-1930)\end{array}$ \\
\hline Intercept & $\begin{array}{l}-5.21 * * * \\
\left(\begin{array}{l}0.39) \\
\end{array}\right.\end{array}$ & 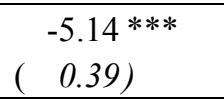 & 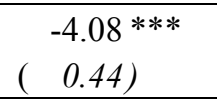 \\
\hline \begin{tabular}{|l|} 
Ratio of Branches to Total \\
Bank Offices (lagged)
\end{tabular} & $\begin{array}{l}2.41 * * * \\
\left(\begin{array}{l}0.39) \\
\end{array}\right.\end{array}$ & $\begin{array}{l}2.34 * * * \\
\left(\begin{array}{l}0.39) \\
\end{array}\right.\end{array}$ & $\begin{array}{ll} & 0.51 \\
( & 0.45) \\
\end{array}$ \\
\hline Banks Per Capita & $\begin{array}{l}0.66^{*} \\
(0.36) \\
\end{array}$ & $\begin{array}{l}0.67 * \\
(0.35) \\
\end{array}$ & $\begin{array}{l}-0.99 * * * \\
(0.07)\end{array}$ \\
\hline $\begin{array}{l}\text { Share of State Income from } \\
\text { Agriculture }\end{array}$ & $\begin{array}{l}0.04 * * * \\
(0.01)\end{array}$ & 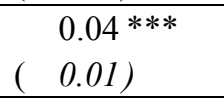 & $\begin{array}{l}0.00 \\
(0.01)\end{array}$ \\
\hline Log Number of Banks & $\begin{array}{l}1.01 * * * \\
(0.06)\end{array}$ & $\begin{array}{l}1.02 * * * \\
(0.06)\end{array}$ & $\begin{array}{l}1.07 * * * \\
(0.07) \\
\end{array}$ \\
\hline Deposit Insurance & $\begin{array}{l}-0.72 * * * \\
(0.18)\end{array}$ & 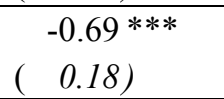 & 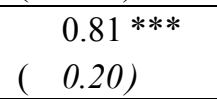 \\
\hline 1924 & $\begin{array}{l}0.20 \\
(0.19)\end{array}$ & $\begin{array}{l}0.01 \\
(0.19)\end{array}$ & $\begin{array}{c}-0.21 \\
(0.21)\end{array}$ \\
\hline 1925 & $\begin{array}{c}-0.02 \\
(\quad 0.20) \\
\end{array}$ & $\begin{array}{c}-0.25 \\
\left(\begin{array}{c}0.20)\end{array}\right)\end{array}$ & $\begin{array}{c}0.13 \\
(\quad 0.20)\end{array}$ \\
\hline 1926 & $\begin{array}{l}0.21 \\
(\quad 0.19)\end{array}$ & $\begin{array}{l}0.05 \\
(0.19)\end{array}$ & $\begin{array}{c}-0.08 \\
(0.21)\end{array}$ \\
\hline 1927 & $\begin{array}{l}0.25 \\
(\quad 0.19)\end{array}$ & $\begin{array}{ll} & 0.18 \\
( & 0.19)\end{array}$ & 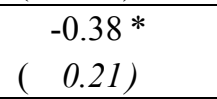 \\
\hline 1928 & $\begin{array}{l}0.19 \\
(\quad 0.19) \\
\end{array}$ & $\begin{array}{ll} & 0.04 \\
( & 0.19) \\
\end{array}$ & 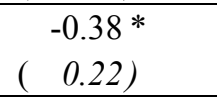 \\
\hline 1929 & 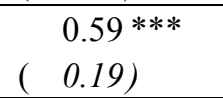 & 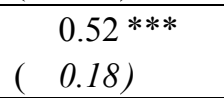 & $\begin{array}{c}-0.02 \\
(0.21)\end{array}$ \\
\hline 1930 & $\begin{array}{l}0.88 * * * \\
(0.19)\end{array}$ & 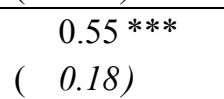 & $\begin{array}{c}-0.27 \\
\left(\begin{array}{c}0.22 \\
(\end{array}\right)\end{array}$ \\
\hline Dispersion & $\begin{array}{l}0.39 \\
(\quad 0.06) \\
\end{array}$ & $\begin{array}{l}0.39 \\
(\quad 0.06) \\
\end{array}$ & $\begin{array}{c}0.54 \\
(\quad 0.08) \\
\end{array}$ \\
\hline $\begin{array}{l}\text { Observations } \\
\text { Log-Likelihood }\end{array}$ & $\begin{array}{c}384 \\
-1031\end{array}$ & $\begin{array}{c}384 \\
-964\end{array}$ & $\begin{array}{c}384 \\
-1086\end{array}$ \\
\hline
\end{tabular}

Note. The symbols $(* * *),(* *)$, and $(*)$ indicate statistical significance at the 1,5 , and 10 percent level, respectively. Standard errors are in parentheses. Data on voluntary liquidations, mergers, and entries of national banks are from the Annual Report of the Comptroller of the Currency (1922-1930). Population and income shares are from 1920 Census report. The first year in each sample period is the omitted year from the regression. Branch offices and total bank offices include both state and national banks. 
Table 6 - Effect of State Branching Law on Voluntary Liquidations, Mergers, and Entry using a Pooled Sample

Dependent variable: The count of voluntary liquidations, mergers, and entries of national banks in a state per year.

\begin{tabular}{|c|c|c|c|}
\hline & $\begin{array}{c}\text { Voluntary } \\
\text { Liquidations } \\
(1922-1930)\end{array}$ & $\begin{array}{c}\text { Mergers } \\
(1922-1930)\end{array}$ & $\begin{array}{l}\text { New Banks } \\
(1922-1930)\end{array}$ \\
\hline Intercept & 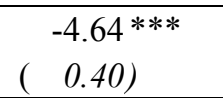 & 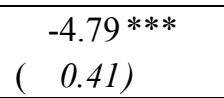 & $\begin{array}{l}-3.87 * * * \\
(\quad 0.43)\end{array}$ \\
\hline Law allows branching & $\begin{array}{l}0.24 * \\
(0.12)\end{array}$ & $\begin{array}{l}0.21 * \\
(0.12)\end{array}$ & $\begin{array}{c}-0.10 \\
(\quad 0.13)\end{array}$ \\
\hline Banks Per Capita & $\begin{array}{c}-0.12 \\
(0.37)\end{array}$ & $\begin{array}{c}-0.04 \\
(0.37)\end{array}$ & $\begin{array}{l}-1.61 * * * \\
(\quad 0.07)\end{array}$ \\
\hline $\begin{array}{l}\text { Share of State Income from } \\
\text { Agriculture }\end{array}$ & $\begin{array}{l}0.03 * * * \\
(0.01)\end{array}$ & $\begin{array}{l}0.03 * * * \\
(0.01)\end{array}$ & $\begin{array}{ll} & 0.00 \\
( & 0.01)\end{array}$ \\
\hline Log Number of Banks & $\begin{array}{l}0.96 * * * \\
(0.06)\end{array}$ & 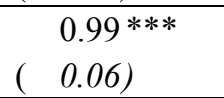 & $\begin{array}{l}1.08 * * * \\
(\quad 0.07)\end{array}$ \\
\hline Deposit Insurance & $\begin{array}{l}-0.45^{* *} \\
\left(\begin{array}{l}0.19 \\
)\end{array}\right)\end{array}$ & $\begin{array}{l}-0.45^{* *} \\
\left(\begin{array}{l}0.19 \\
)\end{array}\right)\end{array}$ & 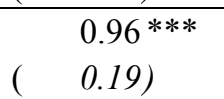 \\
\hline 1923 & $\begin{array}{l}0.19 \\
(\quad 0.22)\end{array}$ & $\begin{array}{ll} & 0.31 \\
( & 0.21)\end{array}$ & $\begin{array}{cc}-0.06 \\
(\quad 0.21)\end{array}$ \\
\hline 1924 & $\begin{array}{l}0.38^{*} \\
(0.22)\end{array}$ & $\begin{array}{l}0.34 \\
(\quad 0.21)\end{array}$ & $\begin{array}{c}-0.28 \\
(\quad 0.22)\end{array}$ \\
\hline 1925 & $\begin{array}{ll} & 0.18 \\
( & 0.22)\end{array}$ & $\begin{array}{l}0.09 \\
(\quad 0.22)\end{array}$ & $\begin{array}{ll} & 0.05 \\
(\quad 0.21)\end{array}$ \\
\hline 1926 & $\begin{array}{l}0.40^{*} \\
(0.22)\end{array}$ & 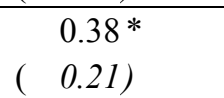 & $\begin{array}{c}-0.15 \\
(\quad 0.22)\end{array}$ \\
\hline 1927 & $\begin{array}{l}0.46^{* *} \\
(0.21)\end{array}$ & $\begin{array}{l}0.55 * * * \\
(0.21)\end{array}$ & $\begin{array}{l}-0.45 * * \\
\left(\begin{array}{l}0.22 \\
)\end{array}\right)\end{array}$ \\
\hline 1928 & $\begin{array}{l}0.43^{* *} \\
(0.22)\end{array}$ & $\begin{array}{l}0.43^{* *} \\
(0.22)\end{array}$ & $\begin{array}{l}-0.45 * * \\
0.22)\end{array}$ \\
\hline 1929 & $\begin{array}{l}0.81 * * * \\
(0.21)\end{array}$ & $\begin{array}{l}0.89 * * * \\
(0.21)\end{array}$ & $\begin{array}{c}-0.09 \\
\left(\begin{array}{l}0.22 \\
(\end{array}\right)\end{array}$ \\
\hline 1930 & 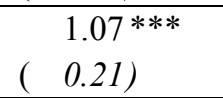 & 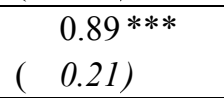 & $\begin{array}{cc} & -0.36 \\
( & 0.22)\end{array}$ \\
\hline Dispersion & $\begin{array}{c}0.56 \\
(\quad 0.07) \\
\end{array}$ & $\begin{array}{r}0.55 \\
(\quad 0.07) \\
\end{array}$ & $\begin{array}{r}0.60 \\
(\quad 0.08) \\
\end{array}$ \\
\hline $\begin{array}{l}\text { Observations } \\
\text { Log-Likelihood }\end{array}$ & $\begin{array}{c}480 \\
-1065\end{array}$ & $\begin{array}{r}480 \\
-968\end{array}$ & $\begin{array}{c}480 \\
-1603\end{array}$ \\
\hline
\end{tabular}

Note. The symbols $(* * *),(* *)$, and $(*)$ indicate statistical significance at the 1,5 , and 10 percent level, respectively. Standard errors are in parentheses. Data on voluntary liquidations, mergers, and entries of national banks are from the Annual Report of the Comptroller of the Currency (1922-1930). Data on branching laws are from the Federal Reserve Board (1931) and population is from the 1920 Census. The first year in each sample period is the omitted year from the regression. 
Table 7 - Branching and Industry Concentration

Dependent variable: concentration indexes

\begin{tabular}{|c|c|c|c|c|c|c|}
\hline & $\begin{array}{l}\text { Herfindah } \\
\text { Coefficient } \\
\text { Estimate }\end{array}$ & $\begin{array}{l}\text { Index } \\
\text { S.E. }\end{array}$ & $\begin{array}{l}\text { 4-Firm I } \\
\text { Coefficient } \\
\text { Estimate }\end{array}$ & dex & $\begin{array}{l}\text { Banks Per } \\
\text { Coefficient } \\
\text { Estimate }\end{array}$ & Capita \\
\hline Intercept & $1084 * * *$ & $(101)$ & $0.21 * * *$ & $(0.02)$ & $38.61 * * *$ & $(2.44)$ \\
\hline $\begin{array}{l}\text { Ratio of Branches to Total } \\
\text { Bank Offices (lagged) }\end{array}$ & $1088 * * *$ & $(301)$ & $0.44 * * *$ & $(0.06)$ & $-69.65 * * *$ & ( 6.34 ) \\
\hline 1924 & & & 0.01 & $(0.03)$ & -2.18 & $(3.39)$ \\
\hline 1925 & & & 0.02 & $(0.03)$ & -3.07 & ( 3.39 ) \\
\hline 1926 & & & 0.02 & $(0.03)$ & -4.20 & $(3.40)$ \\
\hline 1927 & 60 & $(139)$ & 0.03 & $(0.03)$ & -5.31 & $(3.40)$ \\
\hline 1928 & 50 & $(139)$ & 0.04 & $(0.03)$ & $-6.27 *$ & $(3.40)$ \\
\hline 1929 & 101 & $(139)$ & 0.04 & $(0.03)$ & $-6.97 * *$ & $(3.40)$ \\
\hline 1930 & 150 & $(139)$ & 0.05 & $(0.03)$ & $-7.98 * *$ & $(3.40)$ \\
\hline Observations & \multicolumn{2}{|c|}{239} & \multicolumn{2}{|c|}{383} & \multicolumn{2}{|c|}{383} \\
\hline Adjusted R-square & \multicolumn{2}{|c|}{0.04} & \multicolumn{2}{|c|}{0.14} & \multicolumn{2}{|c|}{0.25} \\
\hline
\end{tabular}

Note. The symbols $(* * *),(* *)$, and $(*)$ indicate statistical significance at the 1,5 , and 10 percent level, respectively. Estimated using a pooled sample. Data on the number of banks, size distribution, and number of branches are from the Federal Reserve Board (1931). Four-firm concentration index derived from Polk's Bank Directory (various years) and the Comptroller of the Currency (various years). Population is from the 1920 Census. The dummy for the first year in each time period is the omitted year. Banks per capita and the four-firm index include state and national banks, whereas the Herfindahl index consists only of national banks. 
Table 8 - Effect of Initial Level of Branching on Profitability by Year, 1926 - 1930

Dependent variable: Profit level of banks in different size categories in a state for each year.

\begin{tabular}{|c|c|c|c|c|c|}
\hline & 1926 & 1927 & 1928 & 1929 & 1930 \\
\hline $\begin{array}{l}\text { Ratio of Banks to Total } \\
\text { Bank Offices (1922 value) }\end{array}$ & $\begin{array}{l}1.2 * * * \\
\left(\begin{array}{l}0.2) \\
\end{array}\right.\end{array}$ & $\begin{array}{l}0.6^{* *} \\
\left(\begin{array}{l}0.2) \\
(\end{array}\right)\end{array}$ & $\begin{array}{l}0.1 \\
0.2)\end{array}$ & $\begin{array}{r}-0.4 * \\
0.2)\end{array}$ & $\begin{array}{l}-1.1 * * * \\
0.2)\end{array}$ \\
\hline $\begin{array}{l}\text { Ratio of State Banks to Total } \\
\text { Banks }\end{array}$ & $\begin{array}{l}-1.7 * * * \\
\left(\begin{array}{l}0.1 \\
\end{array}\right) \\
\end{array}$ & 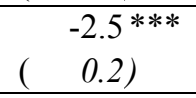 & $\begin{array}{l}-1.9^{* * *} \\
0.2) \\
\end{array}$ & $\begin{array}{l}-0.8 * * * \\
0.2) \\
\end{array}$ & $\begin{array}{l}0.5 * * * \\
0.2)\end{array}$ \\
\hline Deposit Insurance & $\begin{array}{l}-0.4 * * * \\
(\quad 0.1)\end{array}$ & $\begin{array}{l}-0.1^{* *} \\
\left(\begin{array}{l}0.1 \\
(\end{array}\right)\end{array}$ & $\begin{array}{l}0.3 * * * \\
0.1) \\
\end{array}$ & $\begin{array}{l}0.2 * * * \\
0.1)\end{array}$ & $\begin{array}{l}0.3 * * \\
0.1)\end{array}$ \\
\hline Size Category 1 & $\begin{array}{l}-1.6^{* * *} \\
\left(\begin{array}{l}0.1 \\
)\end{array}\right.\end{array}$ & 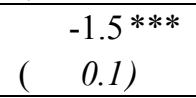 & $\begin{array}{l}-1.6^{* * *} \\
0.1) \\
\end{array}$ & $\begin{array}{l}-1.1 * * * \\
0.1)\end{array}$ & $\begin{array}{l}-0.8 * * * \\
0.1)\end{array}$ \\
\hline Size Category 2 & $\begin{array}{l}-1.1 * * * \\
\left(\begin{array}{l}0.1 \\
(\end{array}\right)\end{array}$ & 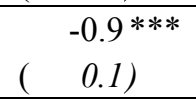 & $\begin{array}{l}-0.9 * * * \\
0.1)\end{array}$ & $\begin{array}{l}-0.7 * * * \\
0.1)\end{array}$ & $\begin{array}{l}-0.5 * * * \\
0.1)\end{array}$ \\
\hline Size Category 3 & 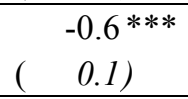 & 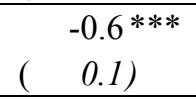 & $\begin{array}{l}-0.5 * * * \\
0.1)\end{array}$ & $\begin{array}{l}-0.3 * * * \\
0.1)\end{array}$ & $\begin{array}{l}-0.1 * * \\
0.1)\end{array}$ \\
\hline Size Category 4 & 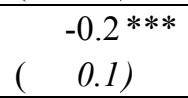 & 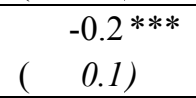 & $\begin{array}{l}-0.1 * * \\
0.1)\end{array}$ & $\begin{array}{c}-0.1 \\
0.1)\end{array}$ & $\begin{array}{l}0.0 \\
0.1)\end{array}$ \\
\hline Size Category 5 & $\begin{array}{c}-0.1 * \\
\left(\begin{array}{c}0.1 \\
(\end{array}\right)\end{array}$ & $\begin{array}{c}-0.1 \\
(\quad 0.1)\end{array}$ & $\begin{array}{c}-0.1 \\
0.1)\end{array}$ & $\begin{array}{l}-0.2 * * * \\
0.1)\end{array}$ & $\begin{array}{l}0.0 \\
0.1)\end{array}$ \\
\hline Size Category 7 & 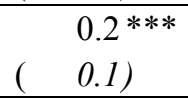 & $\begin{array}{ll} & 0.1 \\
( & 0.1)\end{array}$ & $\begin{array}{l}0.2 * * * \\
0.1)\end{array}$ & $\begin{array}{l}0.3 * * * \\
0.1)\end{array}$ & $\begin{array}{l}0.2 * * \\
0.1)\end{array}$ \\
\hline Size Category 8 & $\begin{array}{ll} & 0.2 \\
(\quad 0.1) \\
\end{array}$ & $\begin{array}{l}0.2 * \\
(\quad 0.1) \\
\end{array}$ & $\begin{array}{l}0.3^{* *} \\
0.1)\end{array}$ & $\begin{array}{l}0.3 * * * \\
0.1)\end{array}$ & $\begin{array}{l}0.4 * * * \\
0.1)\end{array}$ \\
\hline Size Category 9 & $\begin{array}{l}0.2 * \\
(\quad 0.1)\end{array}$ & $\begin{array}{l}0.2 \\
(\quad 0.1)\end{array}$ & $\begin{array}{l}0.3^{* *} \\
0.1)\end{array}$ & $\begin{array}{l}0.6 * * * \\
0.1)\end{array}$ & $\begin{array}{l}0.6^{* * *} \\
0.1)\end{array}$ \\
\hline Size Category 10 & $\begin{array}{ll} & 0.2 \\
( & 0.3)\end{array}$ & $\begin{array}{l}0.0 \\
0.3)\end{array}$ & $\begin{array}{l}0.7 * * \\
0.3)\end{array}$ & $\begin{array}{l}1.1 * * * \\
0.3)\end{array}$ & $\begin{array}{l}1.0 * * * \\
0.3)\end{array}$ \\
\hline Intercept 7 & 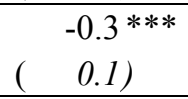 & $\begin{array}{l}0.2 * \\
\left(\begin{array}{l}0.1) \\
\end{array}\right)\end{array}$ & $\begin{array}{l}-0.2 * * \\
0.1)\end{array}$ & $\begin{array}{l}-1.1 * * * \\
0.1)\end{array}$ & $\begin{array}{l}-2.8 * * * \\
0.1)\end{array}$ \\
\hline Intercept 6 & $\begin{array}{l}0.7 * * * \\
\left(\begin{array}{l}0.1)\end{array}\right)\end{array}$ & 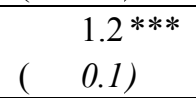 & $\begin{array}{l}0.8 * * * \\
0.1)\end{array}$ & $\begin{array}{c}-0.1 \\
0.1)\end{array}$ & $\begin{array}{l}-1.9 * * * \\
0.1)\end{array}$ \\
\hline Intercept 5 & 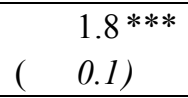 & $\begin{array}{l}2.3 * * * \\
0.1)\end{array}$ & $\begin{array}{l}1.9 * * * \\
0.1)\end{array}$ & $\begin{array}{l}0.9 * * * \\
0.1)\end{array}$ & $\begin{array}{l}-0.9 * * * \\
0.1)\end{array}$ \\
\hline Intercept 4 & $\begin{array}{l}2.7 * * * \\
\left(\begin{array}{l}0.1)\end{array}\right)\end{array}$ & $\begin{array}{l}3.1 * * * \\
0.1)\end{array}$ & $\begin{array}{l}2.8 * * * \\
0.1)\end{array}$ & $\begin{array}{l}1.8 * * * \\
0.1)\end{array}$ & $\begin{array}{l}0.2 \\
0.1)\end{array}$ \\
\hline Intercept 3 & 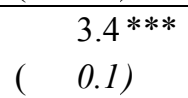 & $\begin{array}{l}3.8 * * * \\
0.1)\end{array}$ & $\begin{array}{l}3.5 * * * \\
0.1)\end{array}$ & $\begin{array}{l}2.5 * * * \\
0.1)\end{array}$ & $\begin{array}{l}0.9 * * * \\
0.1)\end{array}$ \\
\hline Intercept 2 & 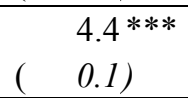 & 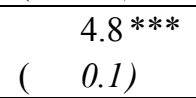 & $\begin{array}{l}4.4 * * * \\
0.1)\end{array}$ & $\begin{array}{l}3.6 * * * \\
0.1)\end{array}$ & $\begin{array}{l}2.1 * * * \\
0.1)\end{array}$ \\
\hline $\begin{array}{l}\text { Observations } \\
\text { Log-Likelihood }\end{array}$ & $\begin{array}{r}1752 \\
-13750 \\
\end{array}$ & $\begin{array}{c}1781 \\
-13634 \\
\end{array}$ & $\begin{array}{c}1737 \\
-13406 \\
\end{array}$ & $\begin{array}{r}1715 \\
-13342 \\
\end{array}$ & $\begin{array}{c}1697 \\
-12962 \\
\end{array}$ \\
\hline
\end{tabular}

Note. The symbols $(* * *),(* *)$, and $(*)$ indicate statistical significance at the 1,5 , and 10 percent level, respectively. Estimated using an ordered logit. Deposit insurance data are from Calomiris (1992) and White (1981). All other information is from the Federal Reserve Board (1931). The dependent variable is an ordered variable indicating the level of profitability weighted by the number of banks that reported earning that level of profits. Size category 6 is omitted. 
Table 9 - Effect of Growth of Branching on Profitability by Year, 1926 - 1930

Dependent variable: Profit level of banks in different size categories in a state for each year.

\begin{tabular}{|c|c|c|c|c|c|}
\hline & 1926 & 1927 & 1928 & 1929 & 1930 \\
\hline $\begin{array}{l}\text { Change in Ratio of Branching to } \\
\text { Total Bank Offices (1922-1925) }\end{array}$ & $\begin{array}{l}2.5^{* * *} \\
0.6)\end{array}$ & $\begin{array}{c}-0.3 \\
(\quad 0.7)\end{array}$ & $\begin{array}{c}-0.9 \\
0.7)\end{array}$ & $\begin{array}{l}-2.1 * * * \\
(0.7)\end{array}$ & $\begin{array}{l}-2.1 * * * \\
0.7)\end{array}$ \\
\hline $\begin{array}{l}\text { Ratio of State Banks to Total } \\
\text { Banks }\end{array}$ & 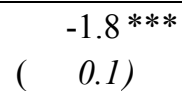 & $\begin{array}{l}-2.6 * * * \\
0.2)\end{array}$ & $\begin{array}{l}-2.0 * * * \\
0.2)\end{array}$ & $\begin{array}{l}-0.9 * * * \\
0.2)\end{array}$ & $\begin{array}{l}0.5 * * * \\
0.2)\end{array}$ \\
\hline Deposit Insurance & $\begin{array}{l}-0.4 * * * \\
\left(\begin{array}{l}0.1 \\
)\end{array}\right.\end{array}$ & 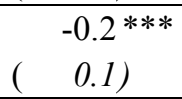 & $\begin{array}{l}0.2 * * * \\
0.1)\end{array}$ & $\begin{array}{l}0.2 * * * \\
\left(\begin{array}{l}0.1)\end{array}\right)\end{array}$ & $\begin{array}{l}0.3 * * \\
0.1)\end{array}$ \\
\hline Size Category 1 & $\begin{array}{l}-1.6^{* * *} \\
\left(\begin{array}{l}0.1 \\
)\end{array}\right)\end{array}$ & $\begin{array}{l}-1.5 * * * \\
0.1)\end{array}$ & $\begin{array}{l}-1.6^{* * *} \\
0.1)\end{array}$ & $\begin{array}{l}-1.1 * * * \\
0.1\end{array}$ & $\begin{array}{l}-0.8^{* * *} \\
(\quad 0.1)\end{array}$ \\
\hline Size Category 2 & $\begin{array}{l}-1.1 * * * \\
(\quad 0.1)\end{array}$ & $\begin{array}{l}-1.0^{* * *} \\
(\quad 0.1)\end{array}$ & $\begin{array}{l}-0.9 * * * \\
(\quad 0.1)\end{array}$ & $\begin{array}{l}-0.7^{* * *} \\
(\quad 0.1)\end{array}$ & $\begin{array}{l}-0.5^{* * *} \\
(\quad 0.1)\end{array}$ \\
\hline Size Category 3 & $\begin{array}{l}-0.6 * * * \\
(\quad 0.1)\end{array}$ & 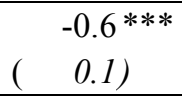 & $\begin{array}{l}-0.5 * * * \\
\left(\begin{array}{l}0.1 \\
(\end{array}\right)\end{array}$ & 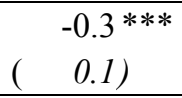 & $\begin{array}{c}-0.1^{*} \\
(\quad 0.1) \\
\end{array}$ \\
\hline Size Category 4 & $\begin{array}{l}-0.2 * * * \\
\left(\begin{array}{l}0.1 \\
)\end{array}\right.\end{array}$ & 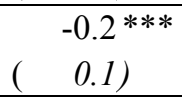 & $\begin{array}{l}-0.1 * * \\
\left(\begin{array}{l}0.1 \\
\end{array}\right)\end{array}$ & $\begin{array}{c}-0.1 \\
(\quad 0.1)\end{array}$ & $\begin{array}{l}0.0 \\
0.1)\end{array}$ \\
\hline Size Category 5 & $\begin{array}{c}-0.1 * \\
\left(\begin{array}{c}0.1 \\
)\end{array}\right)\end{array}$ & $\begin{array}{c}-0.1 \\
(\quad 0.1)\end{array}$ & $\begin{array}{c}-0.1 \\
(\quad 0.1)\end{array}$ & $\begin{array}{l}-0.2 * * * \\
\left(\begin{array}{l}0.1 \\
)\end{array}\right.\end{array}$ & $\begin{array}{l}0.0 \\
0.1)\end{array}$ \\
\hline Size Category 7 & $\begin{array}{l}0.2 * * * \\
(\quad 0.1)\end{array}$ & $\begin{array}{ll}0.1 \\
(\quad 0.1)\end{array}$ & $\begin{array}{l}0.2 * * * \\
0.1)\end{array}$ & $\begin{array}{l}0.3 * * * \\
0.1)\end{array}$ & $\begin{array}{l}0.2 * * * \\
0.1)\end{array}$ \\
\hline Size Category 8 & $\begin{array}{ll} & 0.2 \\
( & 0.1) \\
\end{array}$ & $\begin{array}{l}0.2 * \\
(\quad 0.1) \\
\end{array}$ & $\begin{array}{l}0.3^{* *} \\
0.1)\end{array}$ & $\begin{array}{l}0.3 * * * \\
0.1)\end{array}$ & $\begin{array}{l}0.4^{* * *} \\
0.1)\end{array}$ \\
\hline Size Category 9 & $\begin{array}{l}0.2 * \\
(\quad 0.1)\end{array}$ & $\begin{array}{ll} & 0.2 \\
( & 0.1)\end{array}$ & $\begin{array}{l}0.3^{* *} \\
0.1)\end{array}$ & $\begin{array}{l}0.6 * * * \\
0.1)\end{array}$ & $\begin{array}{l}0.6^{* * *} \\
0.1)\end{array}$ \\
\hline Size Category 10 & $\begin{array}{ll} & 0.2 \\
( & 0.3) \\
\end{array}$ & $\begin{array}{ll} & 0.1 \\
( & 0.3) \\
\end{array}$ & $\begin{array}{l}0.7 * * \\
0.3)\end{array}$ & $\begin{array}{l}1.1^{* * *} \\
0.3)\end{array}$ & $\begin{array}{l}1.0 * * * \\
0.3)\end{array}$ \\
\hline Intercept 7 & $\begin{array}{l}-0.3 * * * \\
\left(\begin{array}{l}0.1 \\
)\end{array}\right.\end{array}$ & $\begin{array}{l}0.3 * * * \\
\left(\begin{array}{l}0.1)\end{array}\right)\end{array}$ & $\begin{array}{c}-0.2 \\
(\quad 0.1)\end{array}$ & $\begin{array}{l}-1.0 * * * \\
\left(\begin{array}{l}0.1 \\
)\end{array}\right)\end{array}$ & $\begin{array}{l}-2.9^{* * *} \\
\left(\begin{array}{l}0.1 \\
)\end{array}\right.\end{array}$ \\
\hline Intercept 6 & $\begin{array}{l}0.8 * * * \\
0.1)\end{array}$ & $\begin{array}{l}1.3 * * * \\
0.1)\end{array}$ & $\begin{array}{l}0.8 * * * \\
0.1)\end{array}$ & $\begin{array}{c}-0.1 \\
(\quad 0.1)\end{array}$ & $\begin{array}{l}-2.0 * * * \\
(\quad 0.1)\end{array}$ \\
\hline Intercept 5 & $\begin{array}{l}1.8^{* * *} \\
0.1)\end{array}$ & $\begin{array}{l}2.4 * * * \\
(\quad 0.1) \\
\end{array}$ & $\begin{array}{l}2.0 * * * \\
0.1) \\
\end{array}$ & $\begin{array}{l}1.0 * * * \\
0.1)\end{array}$ & $\begin{array}{l}-0.9^{* * *} \\
(\quad 0.1) \\
\end{array}$ \\
\hline Intercept 4 & $\begin{array}{l}2.7 * * * \\
(\quad 0.1)\end{array}$ & $\begin{array}{l}3.3 * * * \\
\left(\begin{array}{l}0.1) \\
\end{array}\right.\end{array}$ & $\begin{array}{l}2.8 * * * \\
0.1)\end{array}$ & $\begin{array}{l}1.9 * * * \\
0.1)\end{array}$ & $\begin{array}{l}0.1 \\
0.1)\end{array}$ \\
\hline Intercept 3 & $\begin{array}{l}3.4 * * * \\
(\quad 0.1)\end{array}$ & $\begin{array}{l}4.0 * * * \\
0.1)\end{array}$ & $\begin{array}{l}3.5 * * * \\
0.1)\end{array}$ & $\begin{array}{l}2.6 * * * \\
0.1)\end{array}$ & $\begin{array}{l}0.9 * * * \\
0.1)\end{array}$ \\
\hline Intercept 2 & $\begin{array}{l}4.4^{* * *} \\
\left(\begin{array}{l}0.1 \\
\end{array}\right. \\
\end{array}$ & $\begin{array}{l}4.9^{* * *} \\
\left(\begin{array}{l}0.1 \\
\end{array}\right. \\
\end{array}$ & $\begin{array}{l}4.5 * * * \\
0.1)\end{array}$ & $\begin{array}{l}3.7^{* * *} \\
\left(\begin{array}{l}0.1 \\
\end{array}\right.\end{array}$ & $\begin{array}{l}2.1 * * * \\
\left(\begin{array}{l}* 1 \\
\end{array}\right.\end{array}$ \\
\hline $\begin{array}{l}\text { Observations (weighted) } \\
\text { Log-Likelihood }\end{array}$ & $\begin{array}{c}1752 \\
-14369\end{array}$ & $\begin{array}{c}1781 \\
-14101\end{array}$ & $\begin{array}{c}1737 \\
-13758\end{array}$ & $\begin{array}{c}1715 \\
-13511\end{array}$ & $\begin{array}{c}1697 \\
-13070\end{array}$ \\
\hline
\end{tabular}

Note. The symbols $(* * *),(* *)$, and $(*)$ indicate statistical significance at the 1,5 , and 10 percent level, respectively. Estimated using an ordered logit. Deposit insurance data are from Calomiris (1992) and White (1981). All other information is from the Federal Reserve Board (1931). The dependent variable is an ordered variable indicating the level of profitability weighted by the number of banks that reported earning that level of profits. Size category 6 is omitted. 
Table 10 - Branching and Profitability, 1926 - 1930

Dependent variable: Profit level of banks in different size categories in a state and by year.

\begin{tabular}{|c|c|c|}
\hline & $\begin{array}{l}\text { Coefficient } \\
\text { Estimate }\end{array}$ & S.E. \\
\hline $\begin{array}{l}\text { Ratio of Branches to } \\
\text { Total Bank Offices } \\
\text { (lagged) }\end{array}$ & $-0.19 * * *$ & (0.07) \\
\hline $\begin{array}{l}\text { Ratio of State Banks to } \\
\text { Total Banks }\end{array}$ & $-1.29 * * *$ & (0.06) \\
\hline Deposit Insurance & $-0.16 * * *$ & $(0.03)$ \\
\hline Size Category 1 & $-1.36 * * *$ & $(0.05)$ \\
\hline Size Category 2 & $-0.84 * * *$ & $(0.04)$ \\
\hline Size Category 3 & $-0.45 * * *$ & $(0.03)$ \\
\hline Size Category 4 & $-0.15 * * *$ & $(0.03)$ \\
\hline Size Category 5 & $-0.12 * * *$ & $(0.04)$ \\
\hline Size Category 7 & $0.19 * * *$ & $(0.03)$ \\
\hline Size Category 8 & $0.27 * * *$ & $(0.05)$ \\
\hline Size Category 9 & $0.35 * * *$ & $(0.06)$ \\
\hline Size Category 10 & $0.62 * * *$ & $(0.13)$ \\
\hline 1927 & -0.02 & $(0.03)$ \\
\hline 1928 & 0.03 & $(0.03)$ \\
\hline 1929 & $-0.13 * * *$ & $(0.03)$ \\
\hline 1930 & $-0.93 * * *$ & $(0.03)$ \\
\hline Intercept 7 & $-0.59 * * *$ & $(0.05)$ \\
\hline Intercept 6 & $0.38 * * *$ & $(0.05)$ \\
\hline Intercept 5 & $1.43 * * *$ & $(0.05)$ \\
\hline Intercept 4 & $2.34 * * *$ & $(0.05)$ \\
\hline Intercept 3 & $3.07 * * *$ & $(0.05)$ \\
\hline Intercept 2 & $4.12 * * *$ & (0.06) \\
\hline Observations & \multicolumn{2}{|c|}{8640} \\
\hline Log-Likelihood & \multicolumn{2}{|c|}{-69460} \\
\hline
\end{tabular}

Note. The symbols $(* * *),(* *)$, and $(*)$ indicate statistical significance at the 1,5 , and 10 percent level, respectively. Estimated using an ordered logit and pooled observations. Deposit insurance data are from Calomiris and White. All other information is from the Federal Reserve Board (1931). The dependent variable is an ordered variable indicating the level of profitability weighted by the number of banks that reported earning that level of profits. Size category 6 and the year 1928 are also omitted. 
Table 11 - The Effects of Branching Laws on National Bank Failures, 1927 - 1930

Dependent Variable: Number of failing banks in a state in a year

\begin{tabular}{|c|c|c|c|c|}
\hline & \multicolumn{2}{|c|}{ Legal Environment } & \multicolumn{2}{|c|}{ Actual Branches } \\
\hline & $\begin{array}{l}\text { Coefficient } \\
\text { Estimate }\end{array}$ & S.E. & $\begin{array}{c}\text { Coefficient } \\
\text { Estimate }\end{array}$ & S.E. \\
\hline Intercept & $-2.84 * * *$ & $(0.89)$ & $-2.79 * * *$ & $(0.62)$ \\
\hline $\begin{array}{l}\text { Branch Banking } \\
\text { Permitted }\end{array}$ & $-0.79 * * *$ & $(0.21)$ & & \\
\hline $\begin{array}{l}\text { Ratio of Branches to } \\
\text { Total Bank Offices } \\
\text { (1922 value) }\end{array}$ & & & $-4.46 * * *$ & $(1.28)$ \\
\hline Log Banks & $0.65 * * *$ & $(0.11)$ & $0.63 * * *$ & $(0.11)$ \\
\hline 1928 & -0.17 & $(0.30)$ & -0.16 & $(0.30)$ \\
\hline 1929 & 0.16 & $(0.29)$ & 0.16 & $(0.29)$ \\
\hline 1930 & $1.07 * * *$ & $(0.26)$ & 1.04 & $(0.27)$ \\
\hline Dispersion & 0.87 & $(0.20)$ & 0.91 & $(0.20)$ \\
\hline Observations & \multicolumn{2}{|c|}{192} & \multicolumn{2}{|c|}{192} \\
\hline Log-Likelihood & \multicolumn{2}{|c|}{-8.2} & \multicolumn{2}{|c|}{-7.8} \\
\hline
\end{tabular}

Note. The symbols $(* * *),(* *)$, and $(*)$ indicate statistical significance at the 1,5 , and 10 percent level, respectively. Estimated using pooled data and count data analysis with a negative binomial distribution. Information on bank failures is from the Annual Report of the Comptroller. Information on the number of banks and branching laws is from the Federal Reserve Board (1931). The dummy for the year 1926 is omitted. 
Table 12 - Effects of Initial Level of Branching on National Bank Failures, 1927 - 1930

Dependent Variable: Average number of failing banks in each group (where a group is a set of banks in a similar size category in a state)

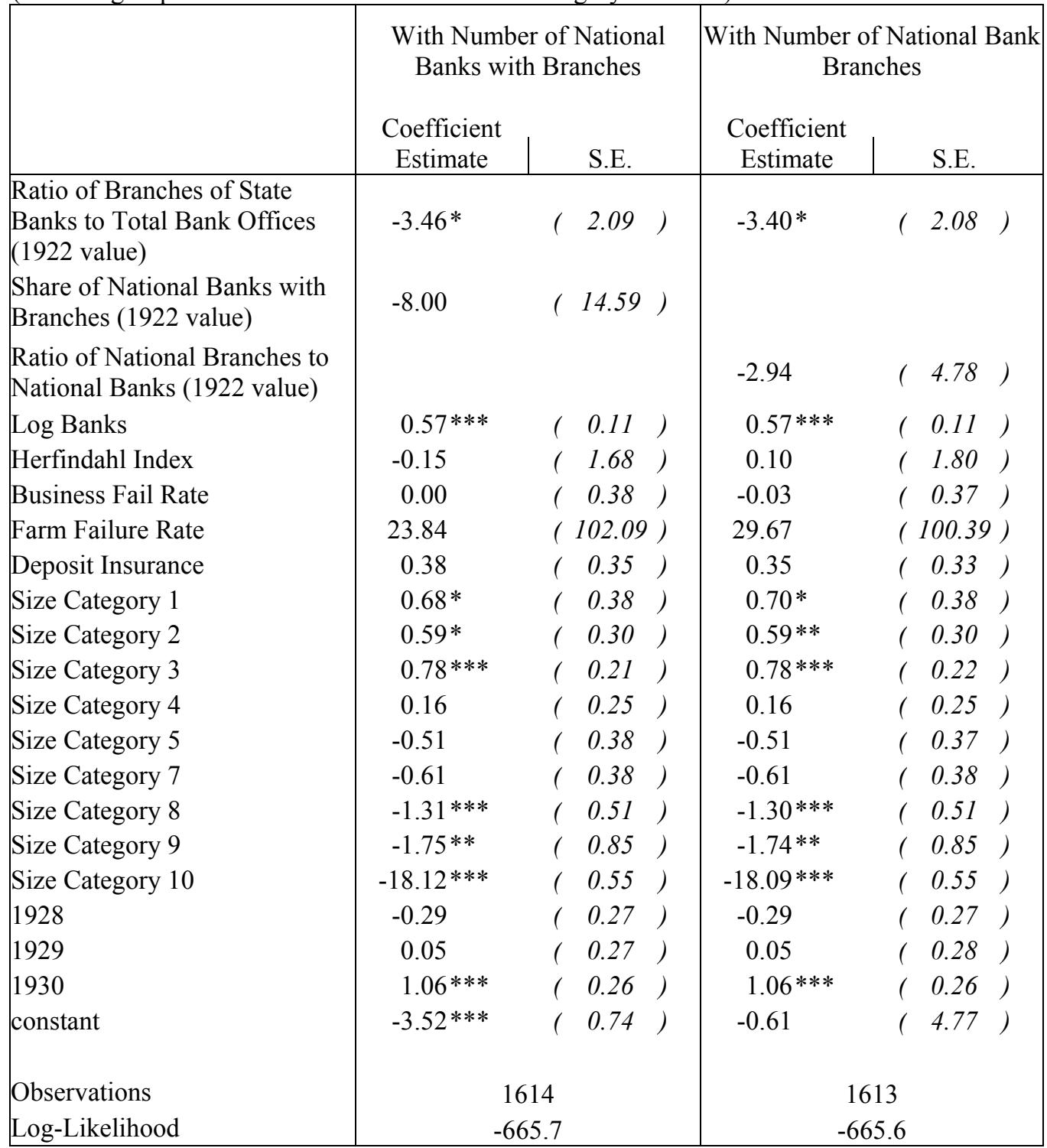

Note. The symbols $(* * *),(* *)$, and $(*)$ indicate statistical significance at the 1,5 , and 10 percent level, respectively. Estimated using a negative binomial distribution. Standard errors are clustered to account for multiple observations from the same state. Data on bank failures are from the Annual Report of the Comptroller of the Currency (1932). Data on the number of bank, size distribution, branching laws, and number of branches is from the Federal Reserve Board (1931). Business failure rates are from the U.S. Department of Commerce and farm foreclosures from the Department of Agriculture (1936). Deposit insurance data are from Calomiris (1992) and White (1981). Size category 6 and the year 1927 are omitted. 
Table 13 - Effects of Branching on National Bank Failures using lagged branching, 1927 - 1930

Dependent Variable: Number of failing banks in each group (where a group is a set of banks in a similar size category in a state and by year)

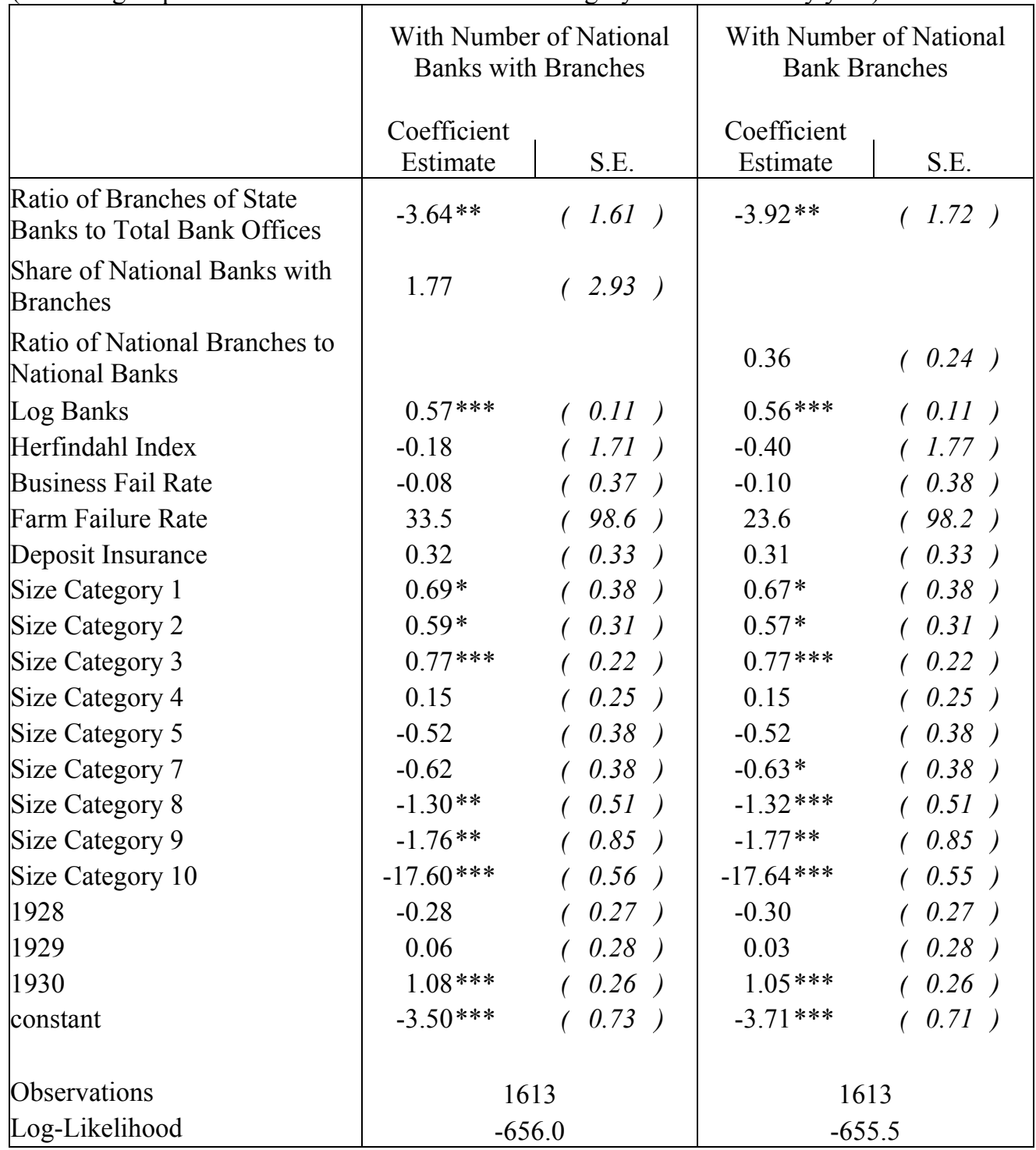

Note. The symbols $(* * *),(* *)$, and $(*)$ indicate statistical significance at the 1,5 , and 10 percent level, respectively. Estimated using a pooled sample and a negative binomial distribution. Standard errors are clustered to account for multiple observations from the same state. Data on bank failures are from the Annual Report of the Comptroller of the Currency (1932). Data on the number of bank, size distribution, branching laws, and number of branches is from the Federal Reserve Board (1931). Business failure rates are from the U.S. Department of Commerce and farm foreclosures from the Department of Agriculture (1936). Deposit insurance data are from Calomiris (1992) and White (1981). Size category 6 and the year 1927 are also omitted. 
Table 14 - Effects of Initial Level of Branching on National Bank Failures excluding California, 1927 1930

Dependent Variable: Average number of failing banks in each group (where a group is a set of banks in a similar size category in a state)

\begin{tabular}{|c|c|c|c|c|c|c|c|c|}
\hline & $\begin{array}{r}\text { With Number } \\
\text { with } \\
\text { Coefficient } \\
\text { Estimate }\end{array}$ & $\begin{array}{c}\text { With Number of National Banks } \\
\text { with Branches }\end{array}$ & $\begin{array}{l}\text { tional B } \\
\text { hes }\end{array}$ & anks & $\begin{array}{r}\text { With Number } \\
\mathrm{Br} \\
\text { Coefficient } \\
\text { Estimate }\end{array}$ & $\begin{array}{l}\mathrm{Na} \\
\text { hes }\end{array}$ & tional E & bank \\
\hline $\begin{array}{l}\text { Ratio of Branches of State } \\
\text { Banks to Total Bank Offices } \\
\text { (1922 value) }\end{array}$ & $-5.96 * * *$ & ( & 2.15 & & $-6.35 * * *$ & & 2.29 & ) \\
\hline $\begin{array}{l}\text { Share of National Banks with } \\
\text { Branches (1922 value) }\end{array}$ & -6.76 & ( & 16.40 & & & & & \\
\hline $\begin{array}{l}\text { Ratio of National Branches to } \\
\text { National Banks (1922 value) }\end{array}$ & & & & & -0.40 & & 4.82 & ) \\
\hline Log Banks & $0.54 * * *$ & ( & 0.11 & ) & $0.54 * * *$ & ( & 0.11 & ) \\
\hline Herfindahl Index & -0.21 & ( & 1.69 & ) & -0.13 & ( & 1.80 & ) \\
\hline Business Fail Rate & -0.08 & ( & 0.38 & ) & -0.10 & & 0.37 & ) \\
\hline Farm Failure Rate & 6.69 & & 103.47 & ) & 13.17 & & 102.09 & ) \\
\hline Deposit Insurance & 0.34 & ( & 0.35 & ) & 0.31 & & 0.33 & ) \\
\hline Size Category 1 & $0.66^{*}$ & ( & 0.39 & ) & $0.67 *$ & ( & 0.39 & ) \\
\hline Size Category 2 & $0.53 *$ & ( & 0.31 & ) & $0.54 *$ & ( & 0.31 & ) \\
\hline Size Category 3 & $0.79 * * *$ & ( & 0.22 & ) & $0.79 * * *$ & ( & 0.22 & ) \\
\hline Size Category 4 & 0.15 & ( & 0.26 & ) & 0.15 & ( & 0.26 & ) \\
\hline Size Category 5 & -0.49 & ( & 0.38 & ) & -0.49 & ( & 0.38 & ) \\
\hline Size Category 7 & -0.65 & ( & 0.40 & ) & $-0.65 *$ & ( & 0.40 & ) \\
\hline Size Category 8 & $-1.30 * *$ & ( & 0.51 & ) & $-1.30 * *$ & ( & 0.51 & ) \\
\hline Size Category 9 & $-1.75 * *$ & ( & 0.86 & ) & $-1.74 * *$ & ( & 0.86 & ) \\
\hline Size Category 10 & $-17.83 * * *$ & ( & 0.58 & ) & $-18.10 * * *$ & ( & 0.59 & ) \\
\hline 1928 & -0.29 & ( & 0.28 & ) & -0.28 & ( & 0.27 & ) \\
\hline 1929 & 0.06 & ( & 0.28 & ) & 0.06 & ( & 0.29 & ) \\
\hline 1930 & $1.06 * * *$ & ( & 0.27 & ) & $1.06 * * *$ & ( & 0.27 & ) \\
\hline constant & $-3.27 * * *$ & ( & 0.75 & ) & -2.90 & ( & 4.80 & ) \\
\hline Observations & \multicolumn{4}{|c|}{1573} & \multicolumn{4}{|c|}{1573} \\
\hline Log-Likelihood & \multicolumn{4}{|c|}{-635.4} & \multicolumn{4}{|c|}{-635.6} \\
\hline
\end{tabular}

Note. The symbols $(* * *),(* *)$, and $(*)$ indicate statistical significance at the 1,5 , and 10 percent level, respectively. Estimated using a negative binomial distribution. Standard errors are clustered to account for multiple observations from the same state. Data on bank failures are from the Annual Report of the Comptroller of the Currency (1932). Data on the number of bank, size distribution, branching laws, and number of branches is from the Federal Reserve Board (1931). Business failure rates are from the U.S. Department of Commerce and farm foreclosures from the Department of Agriculture (1936). Deposit insurance data are from Calomiris (1992) and White (1981). Size category 6 and the year 1927 are omitted. 


\section{Appendix Table 1. Data Sources}

Two main sets of data are employed. The first consists of state-level aggregate data on national banks, covering the period 1922-1930. These data are used to compare the prevalence of entry and exits between states with different branching regimes. Information on number of banks, mergers, voluntary liquidations, and new banks are compiled using the Annual Report of the Comptroller of the Currency (1922-1930).

The second contains additional information on national banks in each state between 1926 and 1930. These data are drawn from the Federal Reserve Board of Governors' (1931) Report on Branch, Chain and Group Banking, Volume 9: Bank Profits and further categorize banks by size (based on the sum of loans and investments). This source also includes the information on bank profits by size category. Data from this Federal Reserve report are also used for the construction of the Herfindahl index of banking concentration. The four-firm bank concentration index is calculated using data on the four largest national banks in each state from Polk's Bank Directory (various years).

Bank failures for 1926-1930 are taken from the Annual Report of the Comptroller of the Currency (1932, table 43, pp.208-28) and the Comptroller of the Currency's Statements of National Banks (1925-1929), and are matched to the appropriate size category for the appropriate state using the information contained in Federal Reserve Board of Governors (1931).

State bank data are matched to branching laws and to indicators of state economic activity. Information on the branching laws for each state are from the Federal Reserve's Report on Branch, Chain and Group Banking, Volume 2: Branch Banking in the United States. This reports the developments in each state's branch banking laws from 1909 until 1931. Detailed information on state branching laws (including whether the de jure rather than the de facto situation was used) is shown in Appendix Table 2. Information on Deposit Insurance follows Calomiris (1992) and White (1981). Business failures and population estimates are from the U.S. Department of Commerce, Statistical Abstract of the United States (various years). Farm foreclosure (bankruptcies) rates are computed using data from U.S. Department of Agriculture (1936) while income shares are derived from the 1920 Census. 


\section{Appendix Table 2. Branch Banking Laws}

\begin{tabular}{|c|c|c|c|}
\hline State & Type & $\begin{array}{l}\text { Year Law } \\
\text { Passed }\end{array}$ & Notes \\
\hline Alabama & Unit & 1911 & A few banks have branches \\
\hline Arizona & Statewide & 1901 & Branching had been practiced before law came into effect \\
\hline Arkansas & Unit & 1923 & State commissioner authorizes a few "exceptions" \\
\hline California & Statewide & 1909 & Branching had been practiced before law came into effect \\
\hline Colorado & Unit & 1909 & \\
\hline Connecticut & Unit & 1902 & \\
\hline Delaware & Statewide & 1895 & If charter allows \\
\hline Florida & Unit & 1913 & \\
\hline Georgia & Multiple & 1929 & $\begin{array}{l}\text { Branching allowed until 1927, banned until } 1929 \text { when it is permitted in } \\
\text { Savannah and Atlanta }\end{array}$ \\
\hline Idaho & Unit & 1919 & \\
\hline Illinois & Unit & 1923 & Prior to 1923, branches had been "not authorized" \\
\hline Indiana & Unit & 1921 & \\
\hline Iowa & Unit & 1927 & Prior to 1927, branches had been "not authorized" \\
\hline Kansas & Unit* & 1929 & Law against it enacted in 1929. Previously there was no law. \\
\hline Kentucky & Statewide* & 1895 & $\begin{array}{l}\text { In } 1902 \text { the banking authority stated that law did not authorize, but "was } \\
\text { not construed as prohibitive." In } 1909 \text { the courts say the banks can't have } \\
\text { branches but can have "offices to receive deposits and pay checks or } \\
\text { transact other necessary duties not requiring special discretion or business } \\
\text { acumen." Observers at the time noted little difference between these } \\
\text { agencies and branches. }\end{array}$ \\
\hline Louisiana & Limited & 1902 & 2 branches in the same parish \\
\hline Maine & Limited & 1895 & Only in the county of the home office or contiguous counties. \\
\hline Maryland & Statewide & 1910 & Branching had been practiced before law came into effect \\
\hline Massachusetts & Limited & 1928 & $\begin{array}{l}\text { Trusts can have branches in the same city, prior to } 1928 \text { were limited to } \\
\text { one branch }\end{array}$ \\
\hline Michigan & Limited* & 1895 & No law, but a lot of branches in the city of the home office \\
\hline Minnesota & Unit & 1923 & \\
\hline Mississippi & Limited & 1924 & Prior to 1924 , the law had prohibited branches \\
\hline Missouri & Unit & 1899 & \\
\hline Montana & Unit & 1927 & No law prior to 1927 \\
\hline Nebraska & Unit & 1927 & No law prior to 1927 \\
\hline
\end{tabular}


Appendix Table 2, continued

\begin{tabular}{|c|c|c|c|}
\hline Nevada & Unit & 1909 & \\
\hline New Hampshire & Unit* & 1895 & $\begin{array}{l}\text { Commissioner reported that he was not aware of any law prohibiting or } \\
\text { allowing branching. }\end{array}$ \\
\hline New Jersey & Limited & 1895 & \\
\hline New Mexico & Unit & 1915 & $\begin{array}{l}\text { Allows "mercantile corporation which maintains a banking department to } \\
\text { continue operations at its branches." A clause in the law specifically for a } \\
\text { particular corporation. }\end{array}$ \\
\hline New York & Limited & 1919 & Branching within cities of 50,000 \\
\hline North Carolina & Statewide & 1921 & Branching had been practiced before law came into effect \\
\hline North Dakota & Unit* & 1895 & $\begin{array}{l}\text { Branches were not specifically mentioned, but the law was construed as } \\
\text { not permitting them. }\end{array}$ \\
\hline Ohio & Limited & 1923 & In contiguous communities \\
\hline Oklahoma & Unit* & 1895 & No law \\
\hline Oregon & Unit & 1921 & \\
\hline Pennsylvania & Limited & 1927 & $\begin{array}{l}\text { Branches are only permitted in places where national banks have } \\
\text { branches already. Prior to } 1927 \text {, it had been in home office-city only. }\end{array}$ \\
\hline Rhode Island & Statewide & 1908 & \\
\hline South Carolina & Statewide* & 1895 & $\begin{array}{l}\text { No law per se, but instead what the capital requirements would be should } \\
\text { the bank have branches }\end{array}$ \\
\hline South Dakota & Unit* & 1895 & No law \\
\hline Tennessee & Limited* & 1925 & Law unclear, seems to be allowed in the county of the home office \\
\hline Texas & Unit & 1905 & \\
\hline Utah & Unit & 1917 & \\
\hline Vermont & Multiple & 1929 & $\begin{array}{l}\text { Went from "not authorized" to able to establish "agencies" which are } \\
\text { branches in all but name }\end{array}$ \\
\hline Virginia & Multiple & 1928 & In 1922 authorized for anywhere, in 1928 restricted to cities of 50,000. \\
\hline Washington & Unit & 1920 & \\
\hline West Virginia & Unit* & 1929 & $\begin{array}{l}\text { Technically allowed by law from 1925-1929, however the commissioner } \\
\text { of banking did not permit them. }\end{array}$ \\
\hline Wisconsin & Unit & 1909 & \\
\hline Wyoming & Multiple & 1926 & $\begin{array}{l}\text { Law of } 1921 \text { has banks articles of incorp. (AoI) state the "place or places } \\
\text { where its offices be located," while the } 1926 \text { law has the AoI state the } \\
\text { "place where its office..." }\end{array}$ \\
\hline
\end{tabular}

Note: All types are as indicated by law (de jure) except were indicated by a * in which case the de facto type is used. Please consult the table for the reason the de jure is not used.

Source. Federal Reserve Board of Governors (1931), Report of the Branch, Chain, and Group Banking Committee, Volume 9. 